\title{
Advances in pineapple plant propagation
}

\author{
Domingo Haroldo R. C. Reinhardt ${ }^{1}$, Duane P. Bartholomew², Fernanda Vidigal Duarte Souza ${ }^{3}$, \\ Ana Cristina Portugal Pinto de Carvalho ${ }^{4}$, Tullio Raphael Pereira de Pádua ${ }^{5}$, \\ Davi Theodoro Junghans ${ }^{6}$, Aristoteles Pires de Matos ${ }^{7}$
}

\begin{abstract}
Pineapple is one of the most important fruits, with large production in tropical and subtropical regions and great appreciation by consumers all over the world. The pineapple plant has many specific morphological, anatomical and physiological characteristics that determine crucial aspects of pineapple crop management, such as flower induction, water use and vegetative methods of propagation. The use of sexual reproduction of pineapple is restricted to breeding purposes carried out by research institutes looking for new hybrids with improved agronomic characteristics. Seeds are only produced if cross pollination among varieties occurs. Commercially pineapple has to be propagated by vegetative material, an asexual reproduction, without new combinations of genes. Some types of propagules are naturally produced by the plants and called conventional planting material. Its availability and quality depend on many factors, especially cultivar and environment. Management techniques of this material have been continuously developed and will be addressed. In addition to the conventional planting material, which in many situations is not sufficient to assure expansion or at least maintenance of the cultivated area, several other methods of vegetative propagation of pineapple have been studied and made available along the last decades and will also be discussed, involving techniques of stem sectioning, apical growing point gouging and chemical treatment for transformation of flowers into plantlets. Stem sectioning has been especially interesting, as it is mostly done using plant residues available at low cost, and is a rather simple method suited for multiplication and production of disease-free planting material in nurseries. Gouging and chemical treatment are less practiced, but can be applied in ratoon crops, thereby avoiding the loss of the first cycle fruit. Chemical treatment usually results in rather small plantlets, that must be further grown in nurseries before planting them in the field. And finally micropropagation will also be focused, as in vitro production of plantlets is a very important method of multiplication of new pineapple varieties, but this method yet has not been transformed into a common commercial way of pineapple propagation due to the final high cost and to the still high risks of incidence of somaclonal variations among the plantlets produced.
\end{abstract}

Index terms: Ananas comosus comosus, shoots, plantlets, propagules, micropagation.

\section{Avanços na propagação de abacaxi}

Corresponding author: domingo.reinhardt@embrapa.br

Received: March 01, 2017 Accepted: July 14, 2017

Copyright: All the contents of this journal, except where otherwise noted, is licensed under a Creative Commons Attribution License.

\section{$(\mathrm{cc}) \mathrm{EY}$}

Resumo - O abacaxi é uma das frutas mais importantes, com grande produção em regiões tropicais e subtropicais e grande apreço por consumidores em todo o mundo. $\mathrm{O}$ abacaxizeiro tem muitas características morfológicas, anatômicas e fisiológicas específicas que determinam aspectos cruciais do seu manejo agronômico, como indução floral, uso de água e métodos vegetativos de propagação. A utilização da reprodução sexual do abacaxi é restrita a projetos de melhoramento genético realizados por institutos de investigação que procuram novos híbridos com características agronômicas melhoradas. As sementes só são produzidas se ocorrer polinização cruzada entre variedades. Comercialmente o abacaxi deve ser propagado por material vegetativo, uma reprodução assexuada, sem novas combinações de genes. Alguns tipos de mudas são naturalmente produzidos pelas plantas e chamados de material de plantio convencional. Sua disponibilidade e qualidade dependem de muitos fatores, especialmente a cultivar e as condições ambientais. As técnicas de manejo deste material têm sido desenvolvidas continuamente e serão abordadas. Além do material de plantio convencional, que em muitas situações não é suficiente para assegurar a expansão ou pelo menos a manutenção da área cultivada, vários outros métodos de propagação vegetativa do abacaxi têm sido estudados e disponibilizados ao longo das últimas décadas e também serão discutidos, incluindo técnicas de seccionamento do caule, destruição do ponto de crescimento apical e tratamento químico para a transformação de flores em plântulas. O seccionamento do caule tem sido especialmente interessante, pois é feito usando principalmente resíduos de plantas disponíveis a baixo custo e é um método bastante simples, adequado para a multiplicação e produção de material de plantio livre de doenças em viveiros. Os métodos de destruição do ponto de crescimento apical e de tratamento químico são menos praticados, mas podem ser aplicados em soqueiras, evitando assim a perda do fruto do primeiro ciclo. O tratamento químico geralmente resulta em plântulas bastante pequenas, que devem ser cultivadas em viveiros antes de plantá-las no campo. E, finalmente, a micropropagação será focada, pois a produção in vitro de plântulas tornou-se um método muito importante de multiplicação de novas variedades de abacaxi, mas este método ainda não foi transformado em uma prática comercial comum de propagação do abacaxi devido ao alto custo final e aos riscos ainda altos de ocorrência de variações somaclonais nas mudas produzidas.

Termos para indexação: Ananas comosus comosus, mudas convencionais e mudas não convencionais, micropopagação. 


\section{Introduction}

Brazil has been producing more than 40 million tons of fruits a year, ranking third in the world behind China and India. About 2.5 million tons has been the yearly contribution of pineapples, representing about $10 \%$ of world production and placing Brazil among the three major global suppliers of this fruit (FAO, 2014 and IBGE, 2015). This volume has also represented a third place for pineapple among the fruits harvested in Brazil, behind citrus and banana. More than $90 \%$ of the total volume has come from the tropical regions - North, Northeast and Southeast Brazil, with the States of Pará, Paraiba, Minas Gerais and Bahia being responsible for around $60 \%$ of that volume (IBGE, 2015).

Brazil has been appointed as the country of origin of the pineapple plant and an indication of that has been the large genetic variability found among pineapples grown in locations of the Amazon region. The Active Pineapple Germplasm Bank at Embrapa Mandioca e Fruticultura institute in Cruz das Almas, Bahia, one of the largest in the world, contains more than 600 accessions and many were introduced from the Amazon region (CABRAL et al, 2004; SOUZA et al., 2015).

In spite of that significant natural variability, more than $95 \%$ of the commercial pineapple fields in Brazil are made up just by two cultivars - the international 'Smooth Cayenne' cultivar, mostly grown in subtropical Brazil, and the traditional home cultivar Pérola, found all over the country and being responsible for more than $85 \%$ of total pineapple production. Other cultivars are grown in rather small areas, such as MD-2 (Gold), a hybrid developed by the Pineapple Research Institute of Hawaii (BARTHOLOMEW, 2009), and the hybrids Imperial, Vitória, Ajubá, developed by Embrapa Mandioca e Fruticultura (CABRAL et al., 2010; REINHARDT et al., 2012), and Fantástico and Gomo de Mel, recommended by the Instituto Agronômico de Campinas. There is some production of locally selected cultivars in the Amazon region or its transition regions, as for example the cv. Turiaçu in the States of Maranhão and Amazon and the cvs. Quinarí, Rio Branco, Cabeça de Onça, Senador Guiomar and Gigante de Tarauacá in the States of Acre and Rondonia (RITZINGER, 1992; ARAÚJO et al., 2012; SCHERER et al., 2015).

\section{The plant and its main characteristics}

The pineapple (Ananas comosus var. comosus) (COPPENS D'EECKENBRUGGE and LEAL, 2003; COPPENS D'EECKENBRUGGE and GOVAERTS, 2015) is a tropical plant in the Bromeliaceae family with 56 genera and 2,794 species (LUTHER and SIEFF, 1998). In addition to the food value of its fruit, many species are grown for other purposes, such as fiber production for fabrication of bagging material and use as ornamentals
(COLLINS, 1960; CUNHA et al., 1999).

The pineapple plant has a short, thick, club-shaped stem around which grow narrow and rigid trough-shaped leaves. The axillary root system arises from the stem, is fibrous and superficial, with most soil roots restricted to a depth of 0 to $30 \mathrm{~cm}$. On larger plants axillary roots several centimeters long also are found wrapped around the stem above ground where they can absorb water and nutrients that percolate to the base of mature leaves (KRAUSS, 1948). The shoot of adult plants of commercial varieties is a dense and compact rosette of 40 to 80 leaves. The longest leaves of most cultivars reach a length of 0.80 to $1.20 \mathrm{~m}$, whereas the plant diameter, unrestricted by adjacent plants, usually is 1.00 to $1.50 \mathrm{~m}$ (KRAUSS, 1948; COPPENS D'EECKENBRUGGE and LEAL, 2003). When reproductive development begins, the stem apex ceases to produce leaves and begins to produce flowers, typically from 50 to 150 , as the developing terminal inflorescence is borne upward through the leaf whorl by an elongating peduncle. The flowers develop into individual fruitlets that coalesce into a sorosis type infrutescence (OKIMOTO, 1948).

Pineapple plants are rather well adapted to water economy due to morphological, anatomical and physiological characteristics. These include the rosette leaf structure that channels light rains and dew along the stem and into the soil; its ability to absorb water and nutrients through their waxy leaves and aerial roots; its ability to store water in specialized aquiferous leaf tissue; multicellular trichomes that cover the leaves and protect the plant from excessive transpiration by reflecting radiation; a thick cuticle covering the leaf epidermis that restricts water loss by evaporation, location of the stomata in furrows at the lower leaf surface where they also are covered by trichomes, limiting evapotranspiration; and its nocturnal carbon dioxide fixation via the crassulacean acid metabolism (CAM) carbon assimilation pathway, which results in stomatal opening primarily at night when evaporative demand is lowest.

\section{The crop and its main characteristics}

The pineapple can be cultivated in a single cycle or in one or more additional ratoon cycles. The duration of the cycles is variable, depending on environmental conditions, vigor of planting material and the cultural practices applied. In the tropical region of Brazil, which is representative of many pineapple growing areas in the world, the first cycle lasts 14 to 18 months, whereas the ratoon cycles are shorter, taking, in general, about 12 to 14 months (REINHARDT, 2000).

As a typical tropical species, pineapple plants show adequate growth and produce fruits of good quality when grown at air temperatures of 22 to $32^{\circ} \mathrm{C}$ with daily amplitude of 8 to $14^{\circ} \mathrm{C}$ (BARTHOLOMEW et al., 2003; CUNHA et al., 2009). The plant is most productive and 
fruits are of the highest quality when solar irradiance is highest. The optimal annual sun exposure is about 2,500 to 3,000 hours, or 7 to 8 hours of sunlight per day, with a minimum demand of 1,200 to 1,500 hours (REINHARDT, 2001; CUNHA et al., 2009). The pineapple crop is mostly grown in regions of low altitude, up to $400 \mathrm{~m}$, as higher altitudes are usually associated with lower temperature and lower solar irradiation reducing plant growth, fruit size and increasing fruit acidity and crop cycle length (AUBERT et al., 1973; PY et al., 1984; REINHARDT et al., 2013).

The pineapple was classified as a quantitative but not an obligate short-day plant because reproductive development typically occurs during photoperiods of less than about 11 hours but also can occur during longer photoperiods. (VAN OVERBEEK and CRUZADO, 1948; GOWING, 1961; FRIEND and LYDON, 1979; BARTHOLOMEW et al., 2003; BARTHOLOMEW, 2014). In the southern hemisphere, natural flowering occurs mostly from June to August, when the days are shorter and night temperatures are lower. Periods of high cloudiness, reduced sunlight and water stress may sometimes trigger natural flower differentiation in other seasons, as for example in the autumn (April and May) and the springtime (October and November) (REINHARDT et al., 1986). Natural flowering occurs earlier in more developed plants. There is a varietal influence, with plants of the 'MD-2', 'Pérola' and 'Queen' flowering more precociously than those of the 'Smooth Cayenne' and the 'Imperial' cultivars (CABRAL et al., 2010; REINHARDT et al., 2012; BARTHOLOMEW, 2014).

Despite pineapple anatomical and physiological adaptations to drought and the reduced humidity of semiarid climatic conditions, pineapples require a regular supply of water to sustain continuous growth. A commercial crop has a water requirement of 1.3 to 5.0 $\mathrm{mm} /$ day, corresponding to a monthly precipitation of 60 to $150 \mathrm{~mm}$ (ALMEIDA, 2001) or about 1000 to 1500 $\mathrm{mm}$ a year. Optimal water supply provides about 12.5 $\mathrm{mm}$ week $^{-1}$ by drip or overhead irrigation (HEPTON, 2003 ) and air relative humidity averaging $70 \%$ or higher is considered optimal.

The pineapple plant is very sensitive to soil water saturation, which affects its growth and production. It develops best in well-drained soils with good oxygen supply, such as soils with sandy to intermediate texture. It is well adapted to acidic soils with $\mathrm{pH}$ of 4.5 to 5.5 (BARTHOLOMEW \& KADZIMIN, 1977; PINON, 1978; PY et al., 1987), a $\mathrm{Ca} / \mathrm{Mg}$ ratio close to 1.0 and a $\mathrm{K} / \mathrm{Mg}$ ratio below 1.0.

Careful soil preparation, especially to eliminate hard pans, is important to enable adequate growth and a deep pineapple root system, which with poor tilth is rather limited and superficial. A good supply of organic matter in the soil and its protection with a biomass cover is also highly beneficial for pineapple crop development.
Planting is mostly done in double rows at planting densities above 30,000 plants per hectare for 'Pérola', up to 70,000 for 'MD-2' and 'Smooth Cayenne' and more than 120,000 for 'Queen' (FOURNIER et al.,1995). Higher densities are best suited to areas where fields can be irrigated or where precipitation is higher and well distributed. Planting is mostly done during the rainy season for rainfed fields. If irrigated, the fields may be planted at any time of the year, depending on availability of planting material. However, a good choice of planting date, together with the adequate size of the planting material, may allow forcing flowering at a time that will enable fruits to be harvested in commercially favorable periods. Flowering forcing treatments are widely used in pineapple crops and their efficiencies are crucial to get good yields and commercial success. The substances most commonly used for that are calcium carbide and 2-cloroethylphosphonic acid (ethephon). Application is done during the night, early morning or the late afternoon when stomata are mostly open. Floral induction should be performed on well-developed plants, as their size is directly correlated with the weight of the fruit to be harvested 150 to 180 days later. It is recommended to induce flowering of the 'Pérola' cultivar when its largest leaves ('D' leaves) have a minimum fresh weight of 80 $\mathrm{g}$ and a minimum length of $1.00 \mathrm{~m}$, in order to get fruits weighing $1.5 \mathrm{~kg}$ or more (REINHARDT et al., 1987). For 'Smooth Cayenne' plants, Pinon (1978) recommended forced flowering of plants with a minimum ' $\mathrm{D}$ ' leaf length of $80 \mathrm{~cm}$. Estimated plant weights have also been used to guide floral induction and for 'MD-2' and 'Smooth Cayenne', the ratio estimated fresh weight at forcing: predicted fruit weight at harvest increases from about 0.5 in the humid tropics to about 1.0 in the cooler subtropics. Thus, in Thailand, a $4.0 \mathrm{~kg}$ plant at forcing will produce a $2.0 \mathrm{~kg}$ fruit at harvest while in the cooler subtropical environment of Hawaii or Queensland, Australia a $2.0 \mathrm{~kg}$ plant will produce a $2.0 \mathrm{~kg}$ fruit. Over that environmental range, days from forced flowering to harvest will range from about 135 in the tropical environment to greater than 200 in the subtropical one (HEPTON, 2003).

Pineapple crops need to be adequately supplied with nutrients. Organic, as well as mineral fertilization, are important and should be in amounts proportional to the vegetative development of the plants until the flowering forcing treatment. If plants are adequately fertilized at the time of floral initiation, no additional fertilizer should be needed. And weeds must be controlled by integrating mechanical, cultural and, if needed, chemical methods. Soil covering with biomass locally available, such as from previous crop residues, must be a special concern in order to reduce soil and organic matter losses by erosion. 


\section{Propagation}

Commercially the pineapple plant is propagated by vegetative material, an asexual reproduction, without new combinations of genes. However, sexual reproduction is feasible as seeds are produced in the fruits if cross pollination between cultivars occurs, naturally or under controlled conditions. In the case of fields set up by just one variety, only self-pollination occurs, but there is no fertilization because of incompatibility and no production of seeds (COPPENS D'EECKENBRUGGE et al., 1993).

\section{Sexual propagation for breeding purposes}

Sexual reproduction is essential for the generation of new varieties and is successfully used in breeding programs carried out in some institutions over the world, such as Embrapa Mandioca e Fruticultura in Brazil, CIRAD-France, MARDI in Malaysia and DPAQueensland in Australia, as well as by some private companies with leadership on the international market.

In the traditional genetic improvement system, breeders carry out manual cross-pollinations between selected pineapple plants of different cultivars during a simultaneous flowering period synchronized by forced floral induction. Opening of flowers occurs over a period of about three weeks and every day the open flowers are pollinated. At harvest, seeds are separated from the fruit pulp, cleaned of fruit residue, dried and stored for cultivation. Pineapple seeds are small, averaging $5 \mathrm{~mm}$ in length by $2 \mathrm{~mm}$ in width. They have a brown, very resistant leathery integument and a hard and fine endosperm (CABRAL et al., 2003).

Seeds are placed in shallow trays on moistened river sand beds under controlled environmental conditions for germination (JUNGHANS et al., 2015). Germination occurs mostly from two weeks after sowing and rates are high, usually $80 \%$ or more (CHANG et al., 2003). Seedlings have six to eight-leaves within about three months after sowing and are then transplanted to pots with agricultural substrate and are grown under greenhouse or screenhouse conditions. After an additional 9 to 15 months of growth, during which the seedlings reach a minimum size of $25 \mathrm{~cm}$, which is considered adequate for planting in the field, the plants are finally acclimatized in an open nursery. Cultural practices applied are similar to those used for growing conventional planting material, but growth is usually slower and the first sexual cycle longer, taking about 24 months under tropical conditions. The mostly high heterozygosity of the parental cultivars leads to a high segregation in the majority of the important characters observed in the young plants. An initial screening of plants is carried out during this cycle, and plants are selected on the basis of such factors as presence of leaf spines, leaf color, growth vigor, fruit shape, size and internal quality. The selected plants are cloned using their slips, hapas and suckers and go through new growing cycles for further selection and confirmation of their genetic characters (CABRAL et al., 1993).

\section{Vegetative propagation}

Pineapple plants are usually propagated using vegetative planting material. There is a wide variety of types of vegetative material and both cultivar and environment affect the availability and quality of material used to plant commercial fields. The more common types of material produced naturally by the plants (Fig. 1), also referred to as conventional planting material, include: a) Crowns from the top of the fruit; b) Slips from the peduncle directly below the fruit (these pieces usually have a rudimentary (vestigial) fruit or knob at their base); c) Hapas, which develop in the transition zone between the stem and the peduncle (Py et al., 1984); d) Suckers, which originate several to many $\mathrm{cm}$ below the stem-peduncle transition zone. Suckers formed on the lower part of the stem with roots that grow into the ground, are usually called ground suckers (CUNHA and REINHARDT, 2004a).

Non-conventional planting material may be obtained under field or nursery conditions by human interference applying specific techniques; a) Plantlets obtained by sectioning parts of the plant, which enables the development of lateral buds present along the stem of the mother plant or the small stem of the conventional types of planting material mentioned above (Fig. 2); b) Plantlets forced to develop by destroying the apical growing point of vegetative plants (gouging) and stimulating growth of lateral buds; c) Plantlets (propagules) formed instead of flowers and fruitlets by plant treatment with chlorflurenol at flower initiation (HEPTON, 2003).

Finally, there is the method of micropropagation, the multiplication of pineapple in vitro, a technique of great utility especially for the rapid multiplication of new cultivars produced in breeding programs.

Each type of planting material will be addressed below on its characteristics, practical aspects and recent advances related to crop management and multiplication techniques. 


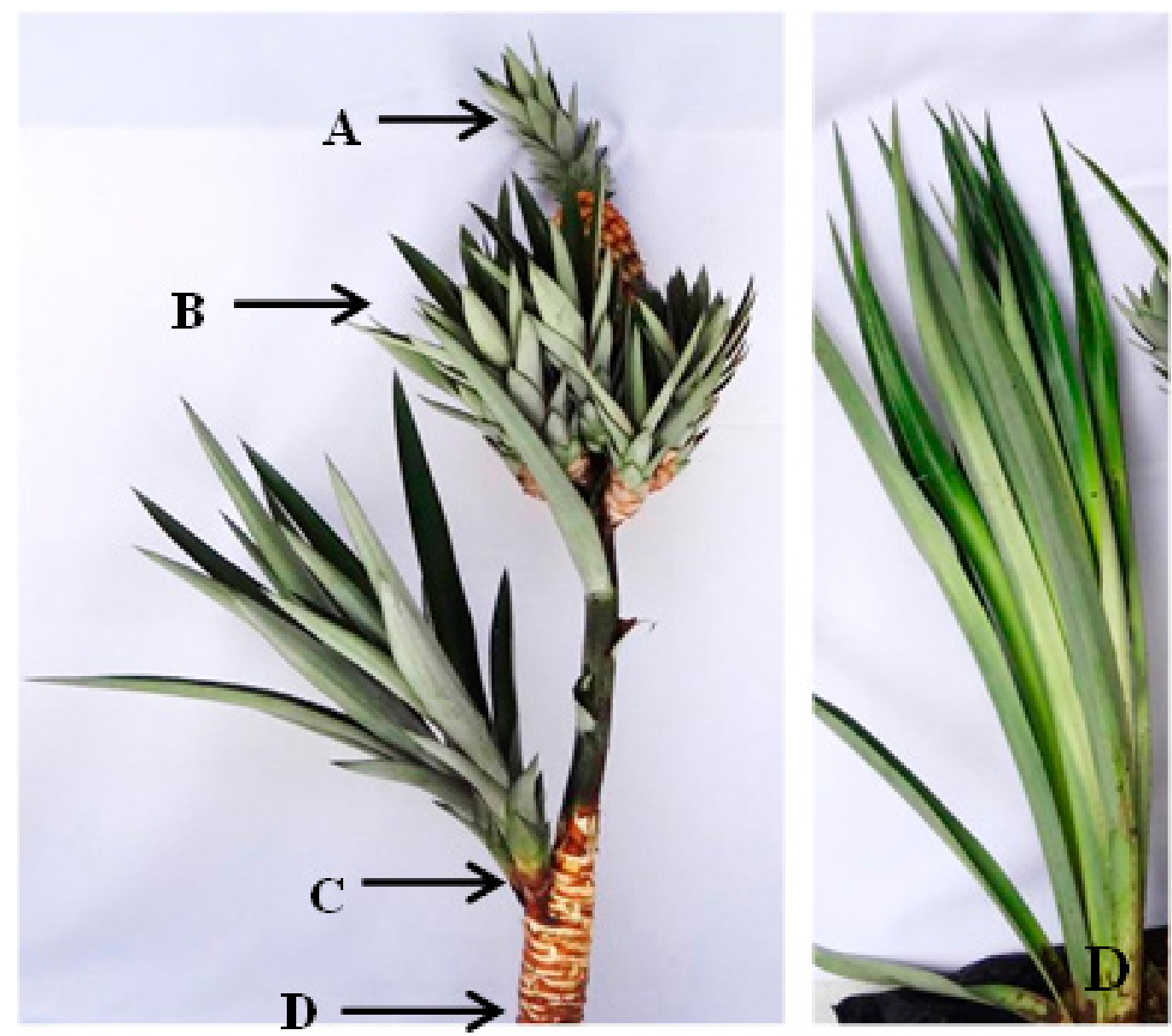

Figure 1. Propagules naturally produced by a pineapple plant, in this case cv. Pérola: A - Crown; B - Slips; C - Hapa; D - Indication of potential Sucker insertion sites.(Photo plate author - Fenanda Vidigal Duarte Souza)

\section{Conventional planting material and its management Crowns}

The conventional planting materials are all botanical shoots and range in average size from crowns, through slips, hapas and suckers, the largest of the group. Crowns are less used than slips and suckers (CUNHA and REINHARDT, 2004b). They are not available where fruits are produced primarily for the fresh fruits market because the fruit is sold with the crown. Also, crowns are unsuitable as planting material if the growing point has been gouged to reduce crown size or in an attempt to increase fruit weight by limiting crown growth during the latter phases of fruit development. However, in fields where fruits are harvested for processing large amounts of crowns may be available and are an inexpensive source of planting material. Crowns may be detached from the fruit and kept in the field or detached at the cannery/processing plant. When left in the field, they have to be selected by weight or size and protected against heart and butt rot with fungicides before planting (HEPTON, 2003). When detached at the cannery, they can be sorted by weight or volume and treated prior to being transported back to prepared fields for planting.
Crowns present some characteristics different from the other types of planting material. They originate from the apical meristem, stop growth when the fruit is mature, may represent up to $40 \%$ of fruit weight, but usually are of low fresh weight (mostly $200 \mathrm{~g}$ or less) in comparison to slips and suckers and hence take longer from planting to harvest in spite of relatively fast rooting (PY, 1969; PY et al., 1987). Due to the presence of remnants of fruit pulp at their base crowns are more susceptible to rotting such as that caused by the fungi Phytophthora parasitica and Chalara paradoxa. Nevertheless, because of their relatively small size they are less susceptible to natural flowering, are usually of more uniform size, which may result in a more uniform response to chemical flower induction with the result being that fruits are more uniform in shape and weight.

Crowns are also available for planting right after fruit harvest, which is an advantage where fruits are harvested throughout the year, but could be of little value where fruits are harvested in one season and fields are planted in a different, e.g., rainy season. In situations where crown numbers are mostly insufficient to meet planting material needs, different types of planting material should not be mixed, but each type should be 
planted in a separate bed, block or field. Mixing different types of planting material within a bed or row will increase the variability of plant sizes present at the time flowering is forced. That variability will result in greater variation in fruit sizes and, in high density plantings, will delay the maturation of fruits on small plants and also reduce their quality (ZHANG, 1992).
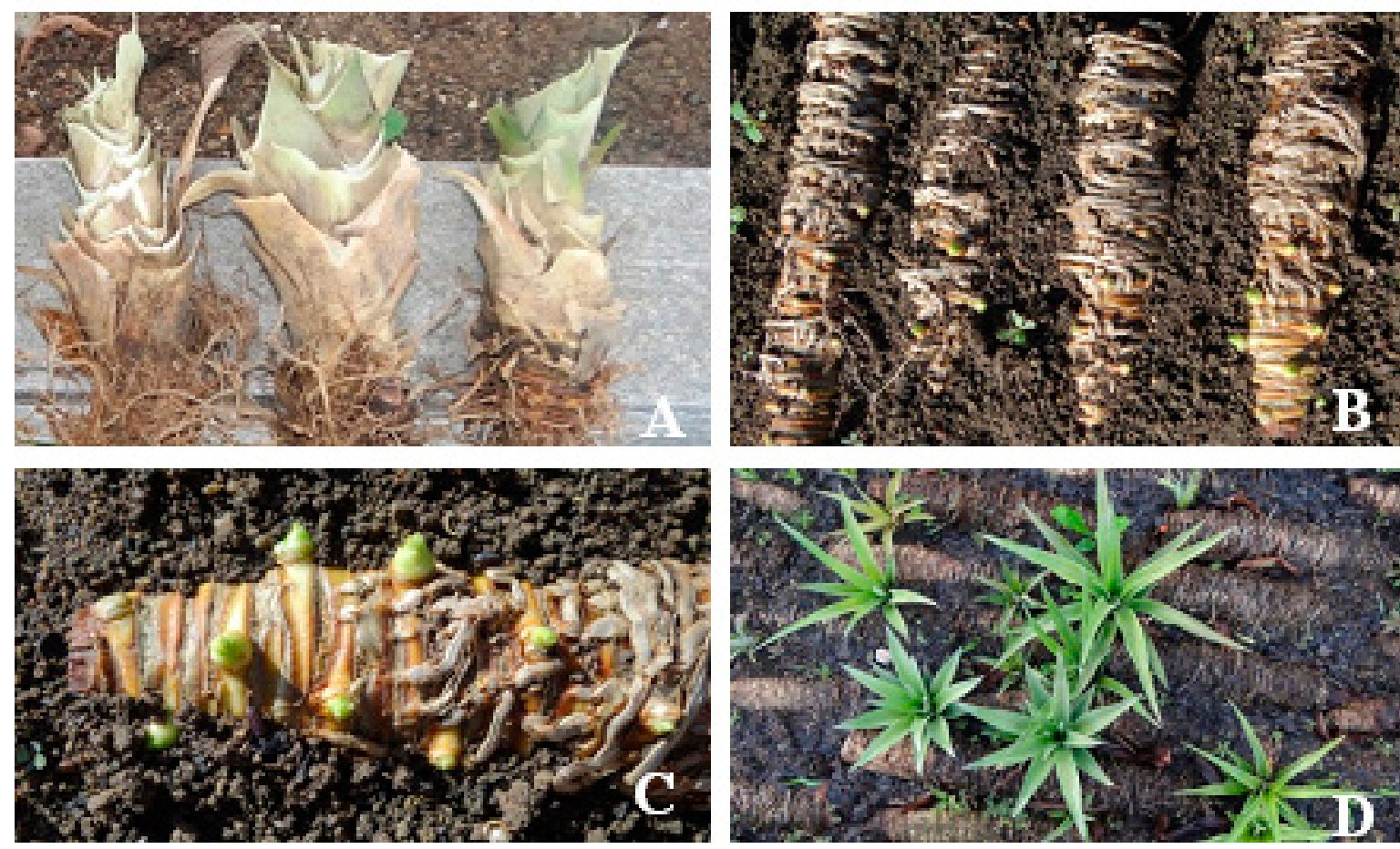

Figure 2. Production of pineapple plantlets using stem sections: A - Stem after cutting off leaves and part of the root system; B - Stem sections planted in a nursery bed after complete removal of leaves and roots; C - Initial sprouting of buds along a stem section; D - Plantlets formed along a stem section. (Photo plate author - Fernanda Vidigal Duarte Souza)

\section{Slips and Hapas}

These shoots are both originated from lateral buds, slips from buds on the peduncle, and hapas in the stem-peduncle transition zone, during fruit initiation. The peduncle elongates after flower formation, forms bracts and a variable number of slips and hapas depending on the clone and cultivar (COLLINS, 1960). Slips can be positioned more or less regularly between the stem and the fruit, at the axis of the bracts, or grouped just beneath the fruit (COPPENS D'EECKENBRUGGE and LEAL, 2003). Slips have a vestigial fruit at their base and can be considered as dwarfed 'aborted' fruits with a relatively large crown (COLLINS, 1960). Slips grow outward and then upward around the base of the fruit, resulting in a sharp curvature at the base of their stem.

Hapas lack a vestigial fruit and emerge in the axils of tightly appressed leaves within the transition zone between the peduncle and the stem. Their base is 'arrow' shaped similar to suckers. Slips and hapas grow in parallel during fruit development and continue to grow after fruit harvest until they are harvested or fall off due to their large weight and weak attachment. Hapas tend to remain on the plant longer than slips because of their lower attachment and greater support provided by a subtending leaf. Just like crowns their only use is as planting material (CUNHA and REINHARDT, 2004a).

There are pineapple varieties that do not produce slips and hapas in any significant number, as for example some clones, e.g., Champaka F153, of cv. Smooth Cayenne, and there are others, as for example cv. Pérola and clones of Smooth Cayenne having the "collar of slips" condition, that bear them in large numbers, reducing average fruit weight and yield (COLLINS, 1960; LIMA et al., 2001, 2002). Temperature also influences slip number. The $\mathrm{cv}$. MD-2 produces relatively large numbers of slips in subtropical environments (Hawaii, at high elevation in Kenya) but produces few or no slips in warm tropical environments such as Ghana. In Brazil, slips are the most important planting material for Pérola, the main traditional cultivar, as well as the more recent ones, such as 'Imperial' and 'Vitória' and these cultivars all produce large average numbers of them (CABRAL and MATOS, 2003). Crowns of the above cultivars are not available to the growers as fruits are sold on the fresh fruit markets together with the crowns.

Slips are a good source of planting material, but overly large vestigial fruits at their base should be removed before planting, as they may rot after planting under wet 
soil conditions. As noted above, the months from planting to harvest for slips is intermediate between the smaller crowns and the larger suckers, as they are also intermediate in size, nutrient reserves and leaf area at planting time (CUNHA and REINHARDT, 2004b).

\section{Suckers}

These are shoots developed from axillary buds at the base of each leaf sheath. In plants of most pineapple cultivars development of these buds is inhibited by the dominance effect of the shoot apex (apical dominance) during the vegetative phase of their cycle. The known exception is 'Queen' clones, for example Victoria, where suckers develop before vegetative growth is terminated by reproductive development (MAERERE, 1995). The extent to which suckers develop during the reproductive phase is highly dependent on the presence of starch reserves in the stem and on the intensity of interplant competition, i.e., plant exposure. Few data exist on the presence of stem starch reserves for any pineapple cultivar; however, stem dry matter content provides a good indication of the presence of reserves and stem dry matter content for 'Smooth Cayenne' declines as average temperature increases (HEPTON, 2003; PY et al., 1987). Thus, while sucker development can occur during the reproductive phase, the extent to which suckers develop during that phase is determined more by the average temperature in the region where the crop is grown and by plant exposure, which determines a plant's photosynthetic capacity. Plant exposure and photosynthetic capacity decline as planting density increases, and suckers per plant decrease as planting density increases (PY et al., 1987). If large reserves are present when the reproductive phase begins sucker development can occur simultaneously with fruit development (PY et al., 1987). However, if reserves and current photosynthesis are insufficient to supply both organs, suckers will not resume their growth until the fruit matures. Much of the growth of suckers occurs after fruit removal and the duration of their growth is determined by their ultimate use. If suckers are to be used as planting material, they would be harvested after reaching a weight of between 300 and $500 \mathrm{~g}$ while if they are to produce a ratoon crop they would need to grow a few to several months before reaching the size needed to produce an acceptable ratoon fruit. The harvesting of suckers to be used as planting material is labor-intensive because they must be cut from the plant.

Suckers can be gathered, stored and shipped without much loss of vigor. They have a characteristic "duck beak" shape at their base, are larger and much less uniform in size and weight than slips and crowns and so require rigorous selection before planting. However, leaf trimming of suckers to remove the top half of the leaves, a common practice for 'MD-2' suckers planted in low elevation fields in Costa Rica, is used to facilitate transport and reduce sensitivity to wind after planting and may also be used to adjust sucker mass to improve plant uniformity (PY et al., 1987).

Suckers are also more susceptible to early flower differentiation, especially the larger ones. However, they reach adequate weight for flower forcing in a shorter time than slips or crowns, reducing the cycle from planting to harvest. A particular problem with large suckers is that they may have undergone floral differentiation before they were harvested for a new planting or the shock of harvesting and storing may have induced differentiation. Once differentiated, these suckers do not grow further and produce a small fruit (HEPTON, 2003).

In warm tropical regions where labor costs tend to be low, suckers are the main planting material for cultivars with low production of slips such as 'Smooth Cayenne' and 'MD-2'. Those two cultivars are the most important cultivars for supplying pineapples on the global market. As suckers develop mostly after fruit harvest, the pineapple field must be maintained until suckers reach adequate size or weight for new plantings. Depending on their size at fruit harvest, it may take from two to four months to get one sucker per plant.

A growers manual for 'Smooth Cayenne' pineapple in the Ivory Coast (IRFA, 1984) indicated that six or more months would be required to get 1.5 suckers per plant. This production may be accelerated and increased by partial pruning of the leaves after fruit removal, as this practice favors sunlight penetration, sucker size and uniformity and harvest, as also reported by Cunha and Reinhardt (2004b) for 'Pérola' pineapples in Brazil.

The application of growth regulators, together with partial leaf pruning, may stimulate sucker production. Suwunnamek (1993) induced more suckers in 'Smooth Cayenne' pineapple by spraying the plants with paclobutrazol alone or together with thiourea or pendimethalin and pruning the leaves two weeks later, facilitating counting and harvesting the suckers produced.

In some pineapple producing regions of the world, the crop undergoes more than one fruiting cycle before a field is replanted. In some cases fruits are harvested for two, three or four cycles, called ratoon crops. Although the yield usually declines with each successive harvest, the costs of production are low because land preparation and replanting are not required. These additional cycles depend on adequate maintenance of the mother-plant root system and the vigorous development of suckers, which are the source of ratoon fruits. These suckers are managed similarly as the first cycle crop until the next fruit maturation and harvest. In Brazil ratoon crops were rather common in the past, even for cv. Pérola fields, but increasing losses caused by fusariosis disease (Fusarium guttiforme), yield reduction and decreasing fruit quality led growers to exploit only the first crop cycle commercially. 


\section{Aspects of management of conventional planting material}

In order to get a uniform pineapple field, planting material must be of good quality and vigor and be subjected to several treatments before planting, such as curing, storing, grading, selecting, dipping, transporting, spreading and finally planting. First of all slips, hapas or suckers must be left growing on the plant after fruit harvest for a period needed to get to an adequate size for use as planting material. In Brazil growers call this period "ceva", a period of "fortification". Depending on environmental conditions and mother plant vigor this period lasts about one to six months for slips and two to twelve months for suckers of cv. Pérola, as most of the suckers start their development only after the fruits are harvested. Cutting the plant shoot horizontally manually or mechanically at a point just above the junction of the peduncle and the stem, stimulates sucker growth, improves uniformity and facilitates its removal. This practice done after fruit harvest and slip removal increases the availability of planting material and has been used in 'Pérola' and 'Smooth Cayenne' pineapple fields in Brazil (REINHARDT et al., 1996; REINHARDT et al., 2002).

If the planting material is ready, but the land is not yet prepared for planting, crowns, slips, hapas and suckers can be stored for days, weeks or even months. In dry periods this should be done in the shade and preferentially in normal vertical position, whereas in humid seasons is better to do it with their base pointing upwards (IRFA, 1984). However, as stored plants continue to grow, stem diameter decreases and storage reserves are consumed, a long storage period results in vigor losses and slows growth and development after planting (PY et al., 1987).

The minimum recommended size for slips, hapas and suckers is $30 \mathrm{~cm}$. Crowns are usually smaller than that and with smaller plants there is greater risk of dropping soil into their rosette center during planting and subsequent cultural practices, which could affect development of the apical meristem and hence of the whole plant. On the other extreme, very large slips and especially suckers are more difficult to handle before and at planting and hence a size of up to 50 or $60 \mathrm{~cm}$ is a recommended limit in most situations.

Grading for size must go together with a rigorous selection of the planting material based upon its vigor, integrity and the absence of pest and disease symptoms. Any material showing rotting symptoms or wax excretions should be discarded, as sick slips and suckers do not develop adequately after planting and may contribute to the dissemination of these pests and diseases in the field.

In Brazil this practice is extremely important in order to minimize Fusarium guttiforme dissemination, a disease that causes large losses of planting material, plants and fruits (MATOS, 1999). In the case of just one slip showing Fusarium symptoms within a bundle of slips harvested from the same plant, it is recommended that the entire bundle be discarded, as some may already be contaminated even though they appear to be free of disease symptoms. The base of slips of the cv. Pérola often has a vestigial fruit of table-tennis ball or even egg size that should be removed before curing and planting to avoid rotting.

After grading and selection for vigor and health the planting material should be cured by exposing it to solar radiation for several days or more. This practice, which helps to accelerate healing of tissue damaged during removal of slips and suckers from the mother plant, prevents rotting, as for example, by Chalara paradoxa, the black rot fungus that may spread very fast in humid and warm environments.

Curing eliminates water excess and partially dehydrated slips and suckers tend to support better longdistance transport to the fields. Curing can be done in the fields by placing the slips and suckers over the mother plants, with their base facing upwards, but for a limited period, usually not longer than two weeks.

This exposure to direct solar radiation also helps to reduce the population of mealybugs (Dysmicoccus brevipes), a very important global pineapple pest that transmits viruses causing wilting of the plants. After the curing period a final selection of the planting material for size, vigor and health is recommended. Slips and suckers should always be separated and planted in different plots. Grading done mechanically by weight is more efficient than grading by size because weight is a better expression of storage reserves, so it improves plant growth and development uniformity.

Dipping the planting material in fungicides and insecticides is a practice used in many pineapple production areas over the world. In many canneries crowns are detached from the fruits at arrival or even in the fields and subjected to a few minutes bath to control black rot disease and mealybugs and mites before their use for new plantings. The same is done with slips, hapas and suckers, if there are high infestations by these pests and environmental conditions favorable to black rot dissemination.

In Brazil this practice is no longer recommended for two reasons: a) The fungicides do not have curative control on planting material already contaminated by Fusarium guttiforme, being much more effective to do a very rigorous selection and discard all plants with symptoms; b) The main cultivar Pérola has shown tolerance to wilting caused by mealybug transmitted viruses.

Once prepared for planting, the material has to be transported to the fields, where workers are in charge of spreading it along the rows thereby facilitating the work of planters. An appropriate amount of planting material should be spread for the areas assigned to be planted, as an oversupply means additional handling that may 
cause damage and affect its performance along the cycle (HEPTON, 2003).

\section{Plantlets and their production}

Plantlets are usually produced where rapid propagation is the objective. Plantlets may be produced in vivo by sectioning of plant material, by plant decapitation (HEENKENDA, 1993), also called gouging, and by chlorflurenol treatment or in vitro by micropropagation.

\section{By plant sectioning}

In spite of the presence of a high number of axillary buds along the well-developed stems of the plant - there is one bud at the base of each leaf - and also of the smaller stems of suckers, hapas, slips and crowns, only a rather small number of buds develop into shoots which become available as planting material. This is due to the apical dominance determined by hormones produced at the stem apex which has a suppressive effect on lateral buds. Apical dominance may be broken by sectioning the stem into pieces containing buds which are released from that suppression and stimulated to grow into plantlets (COLLINS, 1960; PY et al., 1987).

This method of rapid propagation has been especially useful in two situations - first to rapidly multiply new cultivars with low availability of planting material and, second, as a technique for getting planting material free of diseases disseminated by the use of contaminated slips, crowns or suckers. The latter has been of major concern in Brazil due to the severity of fusariosis
(Fusarium guttiforme) in most of the production areas and its local and national dissemination by contaminated planting material (MATOS, 1999). The sectioning of the stems allows recognizing visually internal symptoms of the presence of this fungus and the elimination of affected material both before planting the pieces and during the development of plantlets in the nursery (Fig. 3).

Plantlets obtained from plant sectioning are of superior sanitary quality, but their size, weight and vigor is usually inferior to that of slips and suckers (REINHARDT and CUNHA, 1981; REINHARDT, 1982). Therefore their initial development after planting in the fields is slower and its overall performance is closer to that of small crowns.

\section{Aspects of plantlets production by plant sectioning}

There are several ways for this process to be carried out, depending on factors such as the source of raw material, the size and the infrastructure of the nursery, the cultivar used, the local environmental conditions and even the time period available until reaching the season favorable for planting the plantlets in the field. All these factors will affect requirements for plantlets and yield per area of nursery or per mother plant used for supplying the sections (CUNHA and REINHARDT, 2004b; MATOS et al., 2009). According to these authors the steps until the conclusion of planting of the stem sections in nursery beds include: Selection of plants supplying stems, harvest and preparation of the stems, sectioning, sanitary treatment of the sections, preparation of the nursery beds and planting of the stem sections. Thereafter the cultural practices
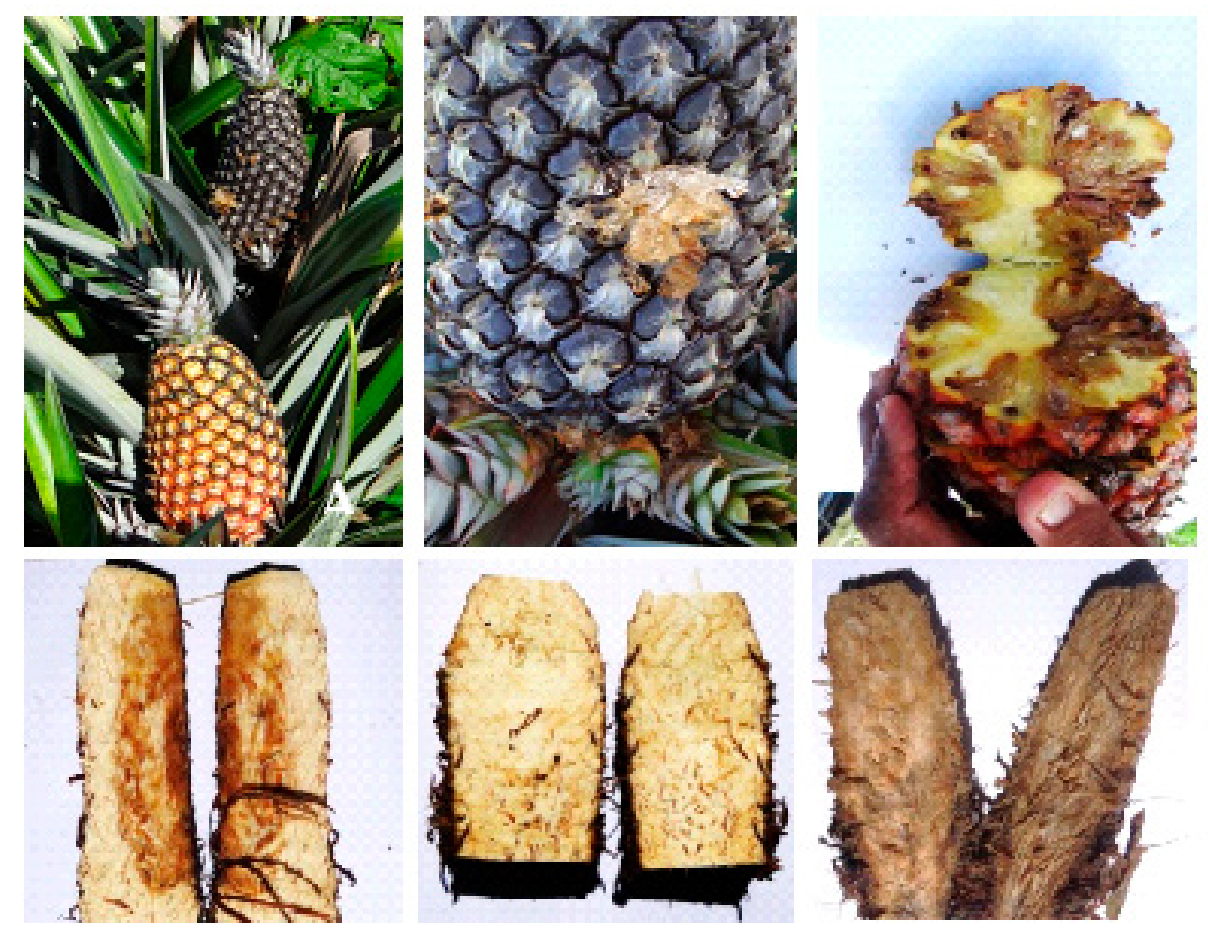

Figure 3. Fusariosis disease (Fusarium guttiforme) symptoms on pineapple cv. Pérola fruits and stem sections: A Fruits with (above) and without (below) symptoms; B - Details of symptoms on the lower part of the fruit and slips; C - Severe internal fruit symptoms; D - Stem sections with symptoms; E - Stem sections without symptoms; E - Stem sections with symptoms all over the tissues. (Photo plate author: Fernanda Vidigal Duarte Souza) 
needed for bud emergence and plantlet development include: Watering, fertilization, weed and pest control, plantlets harvest and grading for field planting.

The selection of plants supplying sections is not an obligatory one, but if focused on plant vigor and health, it may contribute to the improvement of plantlets yield in the nursery and their productive performance in the field (REINHARDT and CUNHA, 1982). If selection is done before fruit harvest, fruit size and shape may be used as additional criteria for selection. Plants selected have to be marked in some way in preparation of their harvest. This harvest should be done as soon as possible after fruit removal, as plant vigor tends to decline over time as stem reserves are consumed during the growth of suckers and ratoon crop development.

Selected plants are removed from the soil and their stems are cleaned by cutting off the entire length of leaves except for the basal sheath portion, peduncle and roots. The basal leaf sheaths help to protect the underlying buds from direct sun radiation and lesioning by sun burning. At this step any stem with external symptoms of fusariosis or any kind of rotting is discarded (REINHARDT and CUNHA, 1981).

After their transport to the nursery location, the stems are cut into pieces. The size of the pieces may be variable; however, pieces containing visible buds and associated with larger storage reserves will develop faster in the nursery than smaller pieces with no visible buds. Reinhardt and Cunha $(1981,1982)$ and Cunha and Reinhardt (2004b) compared the performance in the nursery of stem sections of different sizes from cvs. Pérola and Smooth Cayenne and recommended that the stem be cut into pieces of about $10 \mathrm{~cm}$ length and then to quarter each piece lengthwise. As an alternative they suggested cutting the stems into transverse discs (slices) 2 to $3 \mathrm{~cm}$ thick. The leaf sheath remnant attached to each piece will protect the buds in the event that the nursery beds are not protected against direct sun radiation. During sectioning any pieces with rot or other symptoms of fungal attack are discarded. At this point it is much easier to recognize these contaminations and infections and has been a critical step in eliminating fusariosis and producing healthy planting material in Brazil (CUNHA and REINHARDT, 2004b; MATOS et al., 2009).

The sections are cured by drying, or treated with fungicide, or both, and planted in a well-prepared nursery (HEPTON, 2003). Alternatively, Reinhardt and Cunha (1993) recommended immediate treating and planting of the sections without curing because the high starch content of the sections made them very susceptible to contaminations by fungi such as Penicillium spp. and Chalara paradoxa (black rot), especially under humid environmental conditions. Sections should be dipped into a fungicide-insecticide suspension for at least three minutes to control fungi, mealybugs and mites, pests that are largely present in lower leaf sheaths of pineapple plants. A few hours after this treatment or at the most next morning, the treated stem sections should be planted in the nursery. Disc-form pieces must always be planted horizontally and slightly covered with soil while sections obtained from stems cut lengthwise may be planted vertically, the most common practice, or horizontally, in either case the buds are oriented upwards.. When pieces are planted vertically, they should be covered to at least one-third of their length and the side with buds should face east to protect buds from high sun radiation in the afternoon (CUNHA and REINHARDT, 2004b; MATOS et al., 2009).

Nursery beds may be of variable dimensions, but their length and especially their width must be convenient for carrying out post-planting practices, usually not larger than $1.20 \mathrm{~m}$. The bed should be raised by at least $10 \mathrm{~cm}$ and the soil must drain easily, be well aired and fertile, and these goals may be reached by the application and incorporation of organic and mineral fertilizers some time before planting. And weeds must be controlled, manually, mechanically or even chemically. The application of a pre-emergent herbicide, such as diuron, registered for pineapple crops, over the prepared and humid seedbeds a week before planting the sections, may control most weeds for months and thus reduce the costs and laborforce needs. The same herbicides however, if applied after planting, may affect budding and plantlet development (REINHARDT and CUNHA, 1993).

After planting the nursery beds must be kept under humid conditions. In most situations regular irrigation must be supplied, at least once a day. A soil cover with dry biomass or even with a plastic film may reduce irrigation frequency and help to control weeds. It takes about one to two months until the buds sprout and their leaf growth is clearly visible, a period variable with environmental conditions, cultivar, section size and even mother plant age and vigor.

This initial growth is mostly sustained by the storage reserves of the section, but from about six weeks after planting nutrients should be supplied by foliar feeding with a dilute nutrient solution containing NPK and micronutrients with an initial concentration of about $0.2 \%$ that is gradually increased to $1 \%$ or $1.5 \%$ of commercial product (REINHARDT and CUNHA, 1993; CUNHA and REINHARDT, 2004b). Applications of fungicide and insecticide to keep fungi like Chalara paradoxa, mealybugs (Dysmicoccus brevipes) and mites (Dolichotetranicus floridanus) under control may be necessary depending on environmental conditions. Any plantlet with rot or wilting symptoms must be discarded.

After reaching a minimum size of $30 \mathrm{~cm}$, considered an adequate length for planting in the field, the plantlets are pulled from the soil and separated from the remnant stem section. Usually a significant part of the roots is attached to the section and hence eliminated together with the section. This looks like a negative aspect, as plantlets may develop more rapidly in the field if they have a well-developed root system at the time of planting, an observation made by authors like Hepton (2003). However, the presence 
of roots makes the planting operation more difficult and Nascimento and Reinhardt (2005) have observed that cutting off the whole root system, or at least half of it accelerates and increases the emission of new roots and the dry mass of the root system for several months after planting the plantlets in the field, while roots coming with the plantlets from the nursery tend to decline. This study was done with 'Imperial' pineapple plantlets produced in screenhouses in the tropical region of Cruz das Almas, Bahia, Brazil.

Before taking the plantlets to the field, a last visual selection should be done and any unhealthy looking material eliminated. If grown in nurseries under shade or greenhouse conditions all material should be hardened by gradually increasing the sun exposure before planting.

All the steps described above for stem sections also apply to sections obtained from suckers, slips or crowns, but their apical meristem must be eliminated. These materials usually give smaller pieces than those obtained from plant stems and hence present higher environmental and management requirements for sprouting and development. When rather small sections are produced, they are best planted in sterile media and grown in the greenhouse. Small crown sections should be started in a well-drained medium, such as coarse sand, and must be kept moist. When using a medium of low native fertility, foliar feeding should commence soon after the new shoots emerge (HEPTON, 2003).

There are several plantlet production systems that can be used by growers and planting material producers, as each one has to be adapted to the availability of infrastructure conditions and other needs which influence costs and yield of material ready for planting. As an example may be mentioned the system recommended by Cunha and Reinhardt (2004b), developed for production of Fusarium-free 'Smooth Cayenne' and 'Pérola' pineapple plantlets in Brazil, which presented a performance of 450 to 550 thousand plantlets produced per hectare of nursery, or about eight to ten plantlets per stem, with adequate vigor and health for planting to the fields, within a period of up to ten months.

This same system, using as source pineapple plant stems available after fruit harvest, was improved by Matos et al. (2009) who succeeded in producing more plantlets in the same time period, but with the support of screenhouse conditions. Selected plants had their leaves and the root system completely removed, stems were then longitudinally sliced in half and these treated by immersion in $2 \%$ sodium hypochlorite $\left(\mathrm{NaHClO}_{4}\right)$ solution and/or, if needed, with fungicide and insecticide for five minutes. After quick drying these pieces were planted with their buds directed upwards in a seedbed of washed coarse sand or saw dust within trays distributed inside a screenhouse. Adequate humidity of the environment and the planting medium was maintained using a microsprinkler irrigation system. Within about eight days sprouting of the buds initiated and after 30 to 45 days plantlets reached sizes of at least $2 \mathrm{~cm}$ and were then detached from their stem sections and transplanted to $500 \mathrm{ml}$ tubetes containing organic compost and kept in the same screenhouse conditions. As the plantlets grow they are fed with foliar fertilizers, mostly supplying nitrogen and potash, and are inspected for their vigor and sanitary quality. If needed, pesticides are sprayed.

Matos et al. (2009) reported that this system enabled the production of about thirty plantlets 25 to 30 $\mathrm{cm}$ long, from each stem within six to ten months after planting the sections; however, they emphasized that this yield was variable depending on the cultivar used, the storage reserves of the stem, the environmental conditions and the cultural practices applied.

\section{By destruction of the stem apex (Gouging)}

Gouging is the mechanical removal of the shoot apex of growing plants usually with a tool specifically designed for the purpose (HEENKENDA, 1993). Another way to remove the growing point is by inducing plants to flower and later on breaking off the developing inflorescence (PY et al., 1987).

As Hepton (2003) described, the young leaves are pulled out prior to gouging. Similarly to the sectioning method discussed previously, gouging destroys the plant's apical dominance, thus releasing axillary buds from their induced dormancy. These buds form shoots, which, when large enough, are harvested and planted in a nursery or field. Hepton (2003) reported that plants as small as $100 \mathrm{~g}$ have been gouged, but normally in a greenhouse with fine tools. In the field, plants should be larger (at least $0.5 \mathrm{~m}$ tall) and gouging can be done by workers from a standing position. The gouge should be shallow, preferably not more than about $1.0 \mathrm{~cm}$ below the apex. Treatment of the gouged plants with fungicide is recommended to avoid rot. Shoots produced after gouging are allowed to grow to the desired size and their mass at the time of removal depends on the conditions under which they are to be planted. Very small plants, less than $50 \mathrm{~g}$ or so, would normally be planted in a greenhouse under shade. Plants weighing between 50 and $100 \mathrm{~g}$ could be planted in a propagation bed in the field, while plants weighing 200 $\mathrm{g}$ or more are suitable for use in establishing commercial plantings. A well-maintained mother-plant nursery can be productive for 8-12 months, after which it can either be rejuvenated by allowing at least one low-attached shoot to grow until it is of gouging height or the nursery plants can be diced or removed and the nursery area replanted (HEPTON, 2003).

The number of plantlets obtained with this technique depends on many factors, among those plant vigor, cultivar, environmental conditions and cultural practices, but plantlet size, height or weight, is the most important one. At 'Smooth Cayenne' pineapple fields of IRFA (1984) in Ivory Coast, a so called pseudo-nursery field of very high plant density (100 thousand plants 
per hectare) produced one million plantlets of $100 \mathrm{~g}$ (10 plantlets per plant) or about 300 thousand plantlets of $400 \mathrm{~g}$ (three plantlets per plant) within a period of 18 months after planting. Pinon, cited by Py et al. (1984), obtained six plantlets of $100 \mathrm{~g}$ per plant after 12 months and three additional plantlets in the following six months from a nursery planted with $400 \mathrm{~g}$ suckers of cv. Smooth Cayenne. Flowering of the suckers was forced 2.5 months after planting, followed by removal of the developing inflorescence.

In Sri Lanka, Heenkenda (1993) gouged 'Mauritius' pineapple plants exhibiting at least 31 mature leaves and obtained 4.3 suckers per plant after 87 days . The same author observed that after gouging the production of suckers per plant of cv. Kew did not decrease with increasing planting density up to 70.000 plants per hectare (HEENKENDA, 1995). In Mexico, Rebolledo-Martinez et al. (2005), working with $1.8 \mathrm{~kg}$ plants of the MD-2 cultivar at a planting density of 140.000 plants per hectare, reported a production of 3.8 suckers of individual weight above $200 \mathrm{~g}$ per plant until 150 days after gouging and observed that pruning the plants did not increase this production, whereas application of $3 \mathrm{~L} \mathrm{ha}^{-1}$ of ciclanilide plus ethephon after gouging had a positive effect. In Brazil, gouging of 'Smooth Cayenne' crowns weighing from 200 $\mathrm{g}$ to $300 \mathrm{~g}$, followed by spraying with gibberellic acid and benzylaminopurine, produced per crown on average 5.2 plantlets $35.9 \mathrm{~cm}$ long and weighing $145 \mathrm{~g}$ at 360 days after gouging (COELHO et al., 2007). Inoculation of gouged crowns with mycorrhizae fungi resulted in the production of 23, 14 and 11 plantlets, at least $10 \mathrm{~cm}$ long, per crown respectively of the three main pineapple cultivars in Brazil - Pérola, Smooth Cayenne and Jupi (SANTOS et al., 2011).

\section{By chlorflurenol treatment}

Another way to produce pineapple plantlets is by chemical stimulation of the plant during the initial phase of its reproductive differentiation. Plants are submitted to flower induction treatment following normal farm practice and a week or more later sprayed with a solution of up to $400 \mathrm{ppm}$ of chlorflurenol, a plant growth regulator belonging to the morphactin group, diluted in 30001 per ha (PY et al., 1984). This treatment stimulates the development of propagules in place of flowers and fruitlets.

The number of propagules and their position on the inflorescence depends mostly on the timing and concentration of chlorflurenol. Keetch \& Dalldorf(1977) observed that spraying chlorflurenol solution at one, three, six and nine weeks after the flower forcing treatment resulted in the formation of propagules over the entire inflorescence, over half, a third or none of it, respectively. At nine weeks the effect was mostly a reduction of crown size. The size and number of propagules is rather variable, but they are usually small and formed in large number, that is, up to thirty per plant with an average weight of $60 \mathrm{~g}$ per plantlet (PY et al., 1984). Glennie (1981) obtained 10 propagules of $200 \mathrm{~g}$ per plant in response to spraying $12 \mathrm{mg}$ of chlorflurenol per plant at one week after flowering forcing treatment with ethephon or SNA (sodium salt of NAA - naphthalene acetic acid). In a test carried out at Embrapa, 6.6 to 11.8 propagules per plant were harvested (Fig. 4), with average weights of 33.6 to $24.3 \mathrm{~g}$, respectively, in response to application of $40 \mathrm{~mL}$ per plant of solutions of chlorflurenol at 500 and $1500 \mathrm{ppm}$ at 15 days after flowering forcing treatment with calcium carbide (EMBRAPA/CNPMF, 1981).

Propagules should be carefully graded by size before planting. The small ones have to be grown to larger sizes in a nursery before planting in the field. These propagules may represent an important type of planting material in fresh-fruit operations where crowns are sold with the fruit and the availability of slips or suckers is too low to meet planting-material demands (HEPTON, 2003). However, their production is rather expensive, as plants must be grown to a minimum size for flowering forcing and no fruits are harvested, differing from plantlets obtained by plant stem sectioning after fruit harvest.

In subtropical Hawaii where suckers develop along with the fruits, the costs of propagule production with chlorflurenol were kept low by forcing flowering of shoots that would normally produce a ratoon crop, A few days after forcing the shoots were sprayed with a chlorflurenol solution to initiate propagule production (D. Bartholomew, personal observation). While the ratoon crop was lost, there was no cost of land preparation or planting and little cost except for an occasional nutrient spray to support growth of the suckers and the developing propagules.

\section{By micropropagation}

Micropropagation techniques for obtaining plantlets on a commercial scale have been one of the biotechnological advances with significant impact on agriculture in the last 30 years. Micropropagation has made great contributions to the vegetative reproduction of several crop species, accelerating propagation of new important genotypes and producing a large number of plantlets in a rather short time and often of better quality than that of conventional planting material. The successful application of this technique depends, however, on a number of factors that need to be controlled, such as the genotype, the origin, type and physiological age of the explant, and the culture medium, among others.

Micropropagation protocols of pineapple have been developed and adjusted since the work of Aghion $\&$ Beauchesne (1960). From then many studies have demonstrated the applicability of this technique to the programs of pineapple genetic improvement, as well as for commercial production of plantlets (BE \& DEBERGH, 2006; SOUZA et al., 2009; BARBOZA et al., 2009; ALSAIF et al., 2011; ZURAIDA et al., 2011; SCHERER 


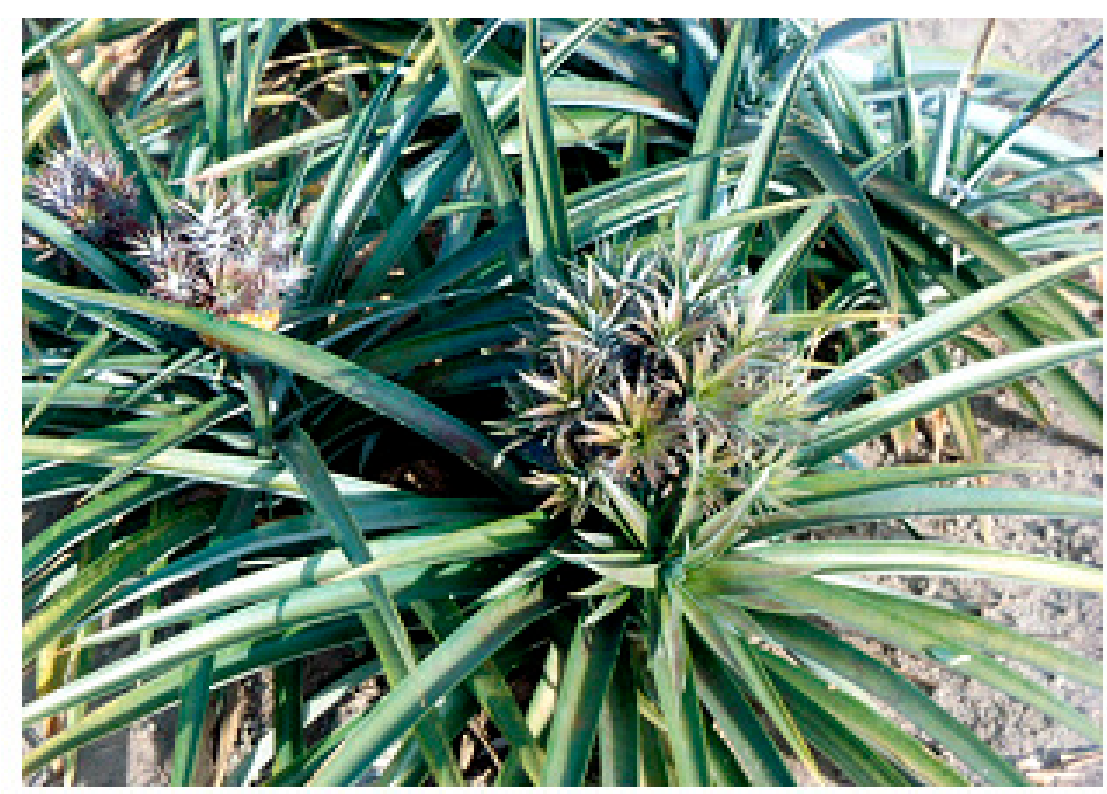

Figure 4. Pineapple plants cv. Smooth Cayenne with propagules developed in response to chlorflurenol treatment. (Author: Domingo Haroldo Reinhardt)

et al., 2013; USMAN et al., 2013; FARAHANI, 2014; NELSON et al., 2015; SCHERER et al., 2015ab; OLIVEIRA-CAUDURO et al., 2016; SILVA et al., 2016; MENDONÇA, et al., 2017).

Currently, conventional techniques of micropropagation have been routinely used in the process of multiplication of new hybrids by research institutions, even though the protocols must be adjusted for each new variety. This process is influenced by many factors, but the most important ones are the genotype, the parent plant, the explant type (part of the plant to start the process) and the culture medium, which will be addressed in the following paragraphs.

The influence of the genotype on the in vitro morphogenetic behavior has been recorded for several species, revealing in most cases responses that define the need for specific protocols (TORRES et al., 1999). In micropropagation of pineapple, the genotype has a strong influence. Silva et al. (2016) evaluated the viability and propagation potential of 66 genotypes of four botanical varieties: 44 genotypes of $A$. comosus var. comosus, 8 of $A$. comosus var. +. bracteatus, 4 of $A$. comosus var. erectifolius and 10 of A. comosus var. ananassoides, all obtained from the Pineapple Active Germplasm Bank. After four subcultures, differences were observed, not only among botanical varieties, but among genotypes of the same botanical variety, confirming this genotype effect on the in vitro multiplication of pineapple.

The parent plant serves as donor of the explant, which is a segment of plant tissue or organ removed from its natural site and used to initiate an in vitro culture. The phytosanitary condition of this material is of crucial importance for the success of the cloning process. Multiplication of infected material as well as the physiological conditions and the sterility of the starting material strongly influence the in vitro morphogenetic potential of the buds. To assure that micropropagated plants are disease free, it is recommended that parent plants be indexed for viruses, especially for the wilt virus transmitted by mealybugs known as PMWaV (Pineapple Mealybug Wilt Associated Virus).

The explants most used for the establishment of in vitro pineapple are axillary buds coming from pineapple slips or hapas, but it is also possible to use buds obtained from suckers. The planting material used may be 15 to $50 \mathrm{~cm}$ long and present 10 to 20 buds, depending on the variety. Pineapple crown buds are another alternative, but they are less available as the crowns are usually sold together with the fruit on fresh fruit markets.

The culture medium basically consists of a mixture of mineral salts, a sugar (usually sucrose) as a source of carbon and energy, growth regulators, amino acids and vitamins, among other components. The basic medium generally is composed of an MS solution (MURASHIGE \& SKOOG, 1962), supplemented with $30 \mathrm{~g} / \mathrm{L}$ of sucrose and a gelling agent, which can be Phytagel ${ }^{\circledR}(1.8 \mathrm{~g} / \mathrm{L})$ or $\operatorname{agar}(8 \mathrm{~g} / \mathrm{L})$, with $\mathrm{pH}$ adjusted to 5.7-5.8.

The addition of auxins and/or cytokines in the initial phase is very variable, according to the diverse protocols published on micropropagation of pineapple (AL-SAIF et al., 2011; USMAN et al., 2013; FARAHANI, 2014; NELSON et al., 2015). Usually no growth regulator is added during the first 45 days of cultivation. Thereafter in the multiplication phase, most researchers recommend the addition of cytokine, especially BAP, used alone or in combination with auxins, such as NAA, IAA and IBA. For pineapple, the concentration of BAP has varied from 0.5 to $4.0 \mathrm{mg} / \mathrm{L}$ for this phase. 
The medium should be prepared and autoclaved at a temperature of $121^{\circ} \mathrm{C}$ and a pressure of $1.05 \mathrm{~kg} / \mathrm{cm}^{2}$, for 15 to 20 minutes. Once disinfested and sterilized, buds are inoculated into the medium and then transferred to a growth room and kept at environmental conditions of $27 \pm 1{ }^{\circ} \mathrm{C}, 22 \mu \mathrm{E} / \mathrm{m}^{2} / \mathrm{s}$ of brightness and 16 hours of photoperiod.

\section{Main stages of the micropropagation process}

Once buds have been removed from the parent plant, the first step is disinfestation to eliminate microorganisms present and thereby minimize the chance of fungal and bacterial contaminations. Under fully aseptic conditions in a laminar flow chamber, these buds should be further reduced removing excess tissue prior to their introduction into the culture medium (Fig. 5A).

The swelling process of pineapple buds (Fig. 5B) is relatively slow and a number of transfers to fresh culture media of same composition are necessary before the start of the multiplication step (Fig. 5C). At 45 days after placing the buds into the culture medium, it is time to add growth regulators. The presence of a cytokinin is critical for initiation of the process of cell division and its balance with an auxin, usually at a ratio of about $3: 1$, favors the elongation and subsequent rooting of plantlets.

When the first shoots or aggregates of shoots appear (Fig.5D), they must be subdivided and transferred to new medium (subculture), and so subsequently in periods of 45 to 60 days, with multiplication rates depending on each variety. The first shoots may appear after about 90 days of cultivation, when the multiplication cycles have to be started by inducing latent buds present at the base of the small shoots, and thus to generate new individuals. Many varieties elongate in this same medium, however, other varieties need to be transferred to specific medium in a larger container for shoot elongation.

Rooting of in vitro pineapple plants (Fig. 5E) can be most often achieved in the absence of growth regulators or with the addition of low auxin concentrations, such as naphthalene acetic acid (NAA), or the combination of auxin with cytokinin.

The last stage of production of plantlets by micropropagation is acclimatization (Fig. 5F). This phase involves the transfer of the plantlets from the in vitro condition to a greenhouse. This passage is quite critical and, in some cases, represents the main limiting factor of the micropropagation process. The plantlets should be carefully removed from the vials, their roots thoroughly washed in running water to remove any residue of the culture medium, and transferred to small Styrofoam trays or tubes (SOUZA et al., 2009), or to another suitable container. As for the substrates, preference should be given to those with low density, good moisture retention and good aeration, including mineral supplementation. According to SOUZA et al. (2009), special care should be taken during acclimatization to prevent substrate from falling into the center ("eye") of the plantlets, which could damage their growing point. The time period needed for acclimatization and development of the plantlets until reaching a minimum size for planting in the field is rather variable. Depending on the variety, environmental and management conditions this period may last up to eight months, but on average takes about five months.

\section{Methods in search of cost reduction and efficiency \\ In spite of its high multiplication rates, pineapple} plantlets produced by micropropagation are rather expensive and production cost reduction has been a major goal (BE \& DEBERGH, 2006; USMAN et al., 2013). Some methods and management practices have been developed looking for lower cost per plantlet obtained, among which can be mentioned the following: the use of a double-phase system, the production of plantlets by means of bioreactors with temporary immersion, etiolation (in vitro shoot elongation) and production of multiple buds in nodal segments.

The double-phase system was first studied by Lima (2009) for pineapple micropropagation. In this system, instead of subculturing the shoots by their transfer to a fresh medium a certain amount of liquid medium is added to the initial half-solid medium in which the explants were inoculated. In addition to the reduction of labor needed for the transfers between culture media, Lima (2009) obtained a higher number of shoots for the three pineapple cultivars studied - Rio Branco, Senador Guiomar and Quinari.

The system of micropropagation in temporary immersion bioreactors was first adapted by Escalona et al. (1998) for large-scale production of pineapple plantlets. It allows the use of large containers, increasing efficiency with cost reduction and excellent survival rates during acclimatization when compared to micropropagation in stationary culture. The establishment of the buds occurs by the conventional micropropagation system, in small containers, and the initial bud aggregates are then transferred to the bioreactors to start the multiplication phase.

This technique alternates temporary immersion of the buds in liquid medium with periods of absence of culture medium, at regular intervals. Each unit of the system consists of two bottles, one containing a large volume of medium depending on the size of the vials and the other with the explants for multiplication. These bottles are interconnected by means of a hose through which the culture medium passes from one bottle to another due to the activation of an air compressor (FEUSER et al., 2001). The interval between immersions of the explants is variable and has to be adapted to the conditions of each species or cultivar. 

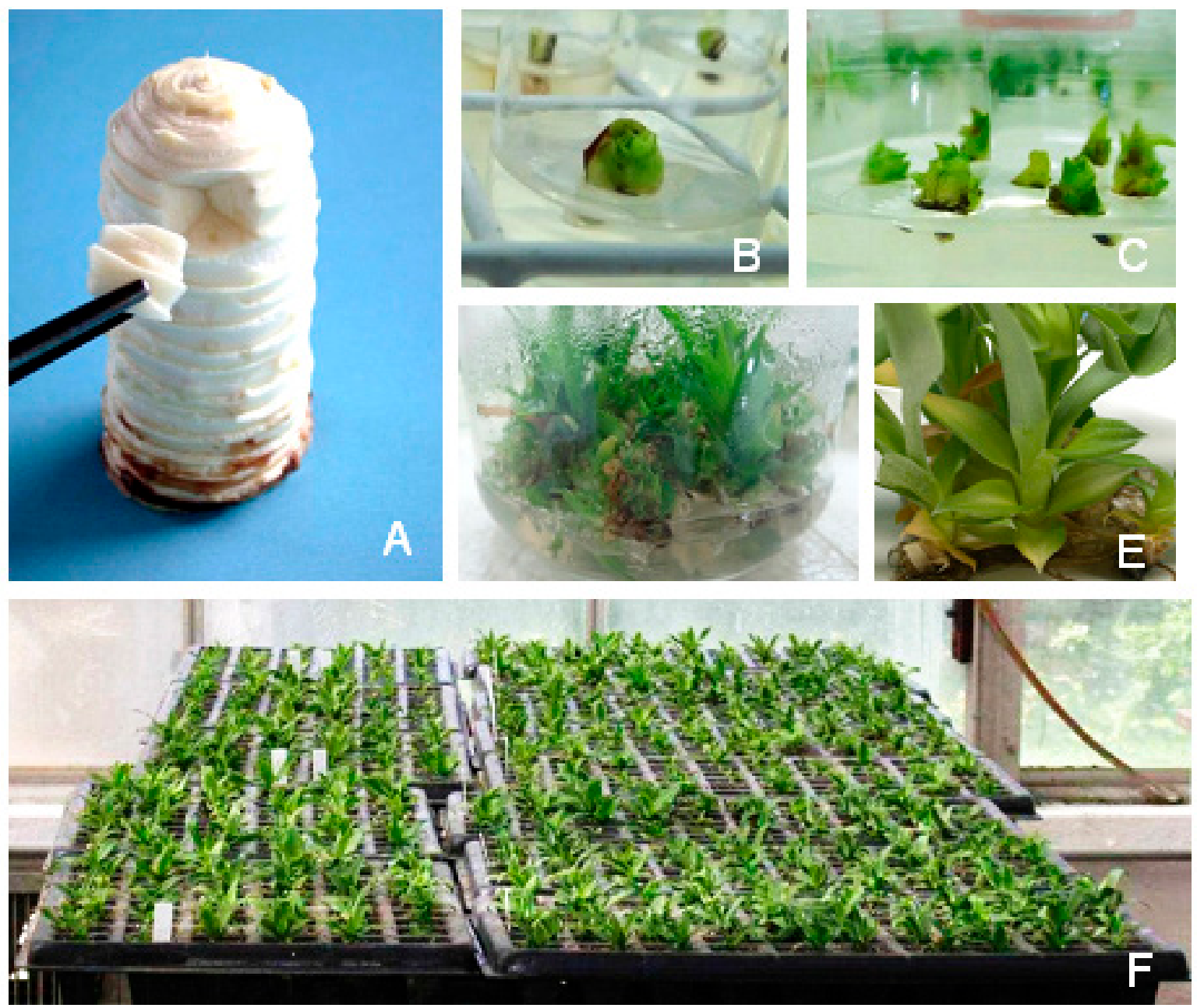

Figure 5. Main stages of pineapple micropropagation: A - Bud extraction from an adult plant stem; B - Bud inoculated into the medium after its disinfestation; $\mathrm{C}$ - Shoot subdivision at the beginning of each subculture; D - Aggregates multiplication and development; E - Plants in rooting medium; F - Acclimated plants in plastic trays. (Photo plate author: Fernanda Vidigal Duarte Souza)

The automation of the system reduces labor force needed for explant transfers between culture media and increases multiplication rates, as it avoids losses of the material by hyperhidration and asphyxia, and hence leads to reductions of plantlets production cost (TEIXEIRA et al., 2001, SCHERER et al., 2013, 2015a,b).

Silva et al. (2007) compared different methods of large-scale production of pineapple plantlets by micropropagation using $\mathrm{cv}$. Imperial: conventional systems in solid medium and in liquid medium (MS medium supplement with $1.00 \mathrm{mg} \mathrm{L}^{-1} \mathrm{BAP}, 0.25 \mathrm{mg} \mathrm{L}^{-1}$ NAA) and micropropagation in temporary and continuous immersion bioreactors. The authors observed that the temporary immersion system was the most efficient method for commercial pineapple micropropagation, which produced more, longer and heavier shoots. However, research efforts continue in search of further efficiency and lower costs per plantlet produced.

The method for pineapple micropropagation based on etiolation (in vitro shoot elongation) of nodal segments was demonstrated by Kiss et al. (1995). In vitro plants were used as explants (Fig. 6A). Shoot etiolation was induced by placing these explants into the MS medium containing NAA $(10 \mu \mathrm{M}=1,86 \mathrm{mg} / \mathrm{L})$ and incubating in darkness at $28^{\circ} \mathrm{C}$ for 30 to 40 days (Fig. 6B); the etiolated shoots, developed in darkness (Fig. 6C), were harvested and placed horizontally into medium supplemented with kinetin $(25 \mu \mathrm{M}=5,38 \mathrm{mg} / \mathrm{L})$ or BA $(20 \mu \mathrm{M}=4,50 \mathrm{mg} / \mathrm{L})$, incubated at $26^{\circ} \mathrm{C}$ and a $16 \mathrm{~h}$ photoperiod, and after 4 to 6 weeks shoots regenerated along the nodes (Fig. 6D); the regenerated plantlets were rooted on growth-regulator-free MS medium (Fig. 6E) and transferred to the greenhouse.

The micropropagation of pineapple by means of nodal segments was reported, for the first time, by Kiss et al. (1995). Thereafter several works were carried out in Brazil with that methodology, such as those done by Moreira et al. (1999, 2003), Barboza \& Caldas (2001), Pereira et al. (2001), Praxedes et al. (2001), Santos et al. (2009) and Souza et al (2010). This method avoids wounding of the regeneration zone and prevents callus production thereby reducing genetic instability and somaclonal variation during multiplication.

Scherer et al. (2013, 2015a, b) established a protocol for micropropagation of pineapple based on nodule cultures associated with different in vitro cultivation systems (Fig.2). The authors reported the establishment 
of an efficient protocol with high multiplication and regeneration rates and great potential for application in agriculture. Based upon biochemical analyses the authors suggested that, in addition to the composition of the culture medium (MS supplemented with $2.00 \mu \mathrm{M}$
NAA and $2.00 \mu \mathrm{M}$ BAP), the flask design and the culture system have crucial effects on the metabolism of the developing plantlets with impacts on their multiplication and regeneration.

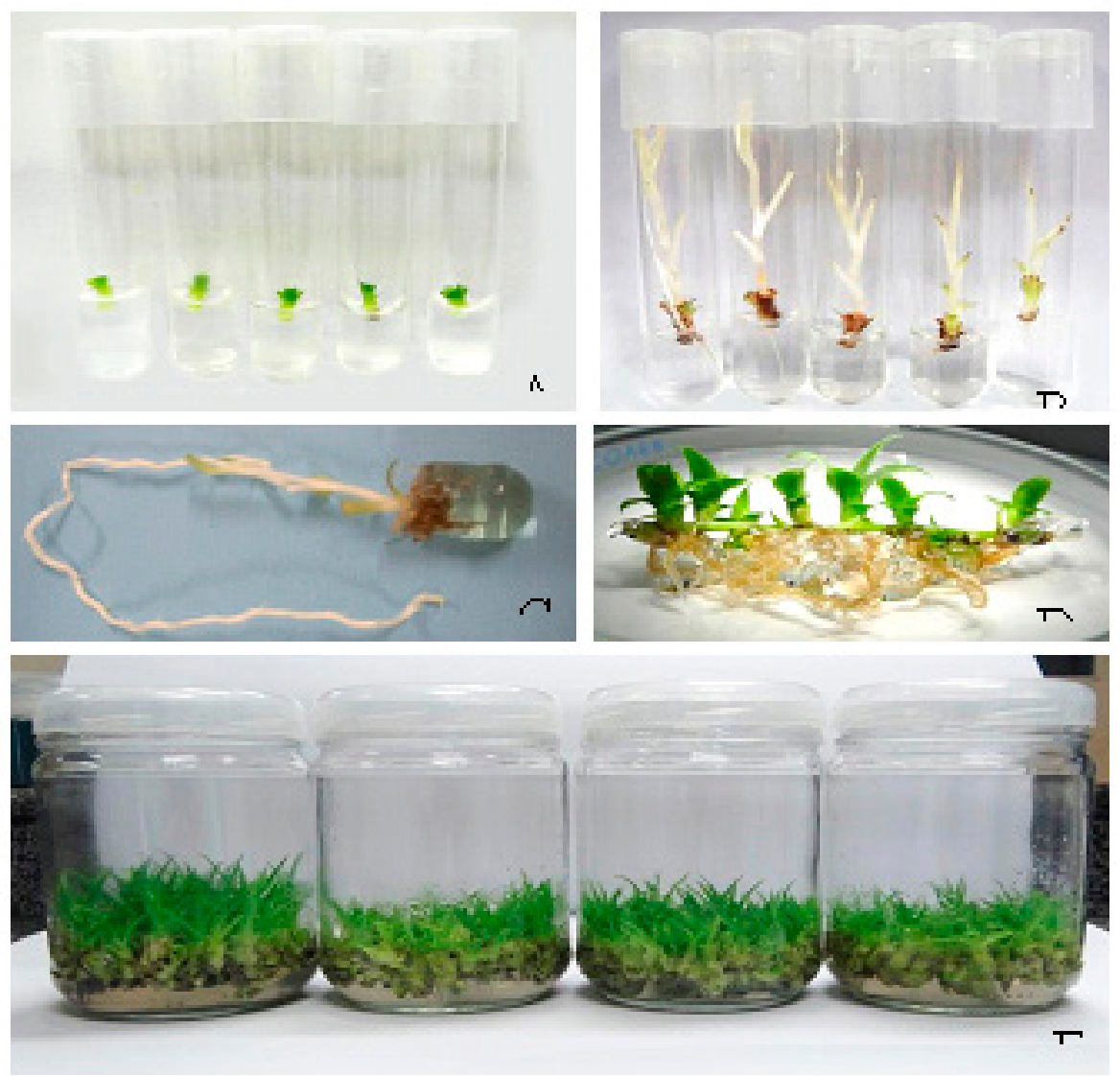

Figure 6. Main stages of pineapple micropropagation by etiolation of nodal segments: A - Plants inoculated for incubation in absence of light; B - Etiolated plants after in darkness incubation; C - Etiolated nodal segment ready for subculture after stem apex elimination; D - Shoots obtained from nodal segments; E - Multiplication phase of the plants. (Photo plate author: Fernanda Vidigal Duarte Souza)

\section{Final statements on micropropagation}

In synthesis, there is no ideal protocol for in vitro propagation of a particular plant species. The methodology needs adjustments for each material in focus and continuous efforts for improvement in search of higher efficiency. With regard to pineapple micropropagation, a large variation in the final number and vigor of plantlets produced has been reported in several studies. Each cultivar requires adjusted protocols, especially regarding the use of adequate concentrations of growth regulators (COSTA et al., 2007; AL-SAIF et al., 2011; USMAN et al., 2013; FARAHANI, 2014; NELSON et al., 2015).
A still critical phase of pineapple plantlet micropropagation is the acclimatization stage, which lasts at least five months and contributes strongly to its final costs, demanding special research efforts. Due to its high cost and, in addition, its often inferior agronomic performance in the first cycle in comparison to conventional planting material, micropropagated plantlets are, in general, not used in commercial pineapple plantings, differing from banana, another important fruit crop of vegetative reproduction. Production costs should be reduced by searching for increasing efficiency in all stages of pineapple micropropagation. And plantlets obtained by micropropagation should get special management after planting in order to fully express their superior genetic and sanitary qualities. 
Final remarks on pineapple propagation

Commercially pineapple is propagated by vegetative methods that restrict their multiplication rates $-\mathrm{a}$ factor that contributes to the slow increases of area cultivated and production of this fruit. The techniques for propagation by use of conventional planting material have been mostly developed 30 or more years ago with little relevant new information added in recent years. In this century research has been mostly focused on refinements of rapid propagation by plant stem sectioning under nursery conditions and especially on micropropagation. The former is important as it needs to be continuously adjusted for new cultivars, whereas the latter, in addition, needs to be further studied in order to reduce costs and to improve the agronomic performance of the plantlets obtained, a crucial condition for broader use of this propagation method for establishing commercial pineapple fields in the future.

\section{References}

AGHION, D.; BEAUCHESNE, G. Utilisation de la technique de culture sterile d'organes pour obtenir des clones d'ananas. Fruits, Paris, v.15, n.10, p.464-466, 1960.

ALMEIDA, O.A. de. Irrigação na cultura do abacaxi: aspectos técnicos e econômicos. Cruz das Almas: Embrapa Mandioca e Fruticultura, 2001. (Circular Técnica, 41).

AL-SAIF, A.M.; HISSAIN, A.B.M.S; TAHA, R.M. Effects of benzylaminopurine and naphthalene acetic acid on proliferation and shoot growth of pineapple (Ananas comosus L. Merr.) in vitro. African Journal of Biotechnology, Nairobi, v.10, n.27, p.5291-5295, 2011.

ARAÚJO, J.R.G.; AGUIAR JÚNIOR, R.A.; CHAVES, A.M.S. et al. Abacaxi 'Turiaçu': cultivar tradicional nativa do Maranhão. Revista Brasileira de Fruticultura, Jaboticabal, v.34, n.4, p.1270-1276, 2012.

AUBERT, B.; GAILLARD, J.P.; PY, C.; LOSSOIS, P.; MARCHAL, J. Influence de l'altitude sur le comportement de l'ananas 'Cayenne Lisse'. Essais realisés au pied du Mont Cameroun. Fruits, Paris, v.28, n.3, p.203-314, 1973.

BARBOZA, S.B.S.C.; CALDAS, L.S. Estiolamento e regeneração na multiplicação in vitro de abacaxizeiro híbrido PE x SC-52. Pesquisa Agropecuária Brasileira, Brasília, DF, v.36, n.3, p.417-423, 2001.
BARBOZA, S.B.S.; TEIXEIRA, J.B.; PORTES, T.A.; COPATI, L.A.; LEDO, A. da S. Cultivo inicial in vitro de gemas axilares de Ananas comosus (L.) Merr., em meio líquido/sólido, na presença/ausência de luz. Ciência Agrotecnologia, Lavras, v.33, p.1832-1836, 2009.

BARTHOLOMEW, D.P.; KADZIMIN, S.B. Pineapple. In: ALVIM, P. de T.; KOZLOWSKI, T.T. Ecophysiology of tropical crops. New York: Academic Press, 1977. p.113-156.

BARTHOLOMEW, D.P.; MALEZIEUX, E.; SANEWSKI, G.M.; SINCLAIR, E. Inflorescence and fruit development and yield. In: BARTHOLOMEW, D.P.; PAULL, R.E.; ROHRBACH, K.G. (Ed.). The pineapple: botany, production and uses. New York: CABI Publishing, 2003. p.167-202.

BARTHOLOMEW, D.P. 'MD-2' pineapple transforms the world's pineapple fresh fruit export industry. Pineapple News, Honolulu, v.16, p.2-5, 2009. Disponível em: $<\underline{\text { http:// }}$ www.ishs-horticulture.org/workinggroups/pineapple/ PineNews16.pdf $>$.

BARTHOLOMEW, D.P. History and perspectives on the role of ethylene in pineapple flowering. Acta Horticulturae, The hague, v.1042, p.269-283, 2014.

BE, L.V.; DEBERGH, P.C. Potential low cost micropropagation of pineapple Ananas comosus. South African Journal of Botany, Amsterdam, n.72, p. 191194, 2006.

CABRAL, J.R.S.; MATOS, A.P. de; JUGHANS, D.T. Desenvolvimento de híbridos de abacaxi resistentes à fusariose. Cruz das Almas: Embrapa-CNPMF, 2003. 4p. (Comunicado Técnico, 88)

CABRAL, J.R.S.; CASTELLEN, M. da S.; SOUZA, F.V.D.; MATOS, A.P. de; FERREIRA, R.F. Banco ativo de germoplasma de abacaxi. Cruz das Almas: Embrapa Mandioca e Fruticultura, 2004. 32p. (Documentos, 146)

CABRAL, J.R.S., MATOS, A.P. de, CUNHA, G.A.P. Selection of pineapple cultivars resistant to fusariose. Acta Horticulturae, The Hague, v.334, p.53-58, 1993.

CABRAL, J.R.S.; MATOS, A.P. de; JUNGHANS, D.T. Cultivar de abacaxi 'Imperial'. Cruz das Almas: Embrapa Mandioca e Fruticultura, 2010. 2p. folder

CHANG,Y.K.; COPPENS D'EECKENBRUGGE, G.; SANEWSKI,G.M. Breeding and variety development. In: BARTHOLOMEW, D.P.; PAULL, R.E.; ROHRBACH, K.G. (Ed.). The pineapple: botany, production and uses. New York: CABI Publishing, 2003.p.33-55. 
COELHO, R.I.; CARVALHO, A.J.C. de; LOPES. J.C.; TEIXEIRA, S.L.; MARINHO, C.S. Coroa do abacaxi 'Smooth Cayenne' na produção de mudas do tipo rebentão. Ciência e Agrotecnologia, Lavras, v.31, n.6, p.1867-1871, nov./dez. 2007.

COLLINS, J.L. The pineapple, botany, utilization, cultivation. London: Leonard Hill, 1960. 294 p.

COPPENS D'EECKENBRUGGE, G.; DURVAL, M. F.; VAN MIEGROET, F. Fertility and self-incompatibility in the genus Ananas. Acta Horticulturae, The Hague, v.334, p.45-51, 1993.

COPPENS D'EECKENBRUGGE, G.; GOVAERTS, R., Synonymies in Ananas (Bromeliaceae). Phytotaxa, Auckland, n.239, p.273-279, 2015.

COPPENS D'EECKENBRUGGE, G.; LEAL, F. Morphology, anatomy and taxonomy. In: BARTHOLOMEW, D.P.; PAULL, R.E.; ROHRBACH, K.G. (Ed.). The pineapple: botany, production and uses. New York: CABI Publishing, 2003. p.13-32.

COSTA, F. H. da S.; PEREIRA, M. A. A.; OLIVEIRA, J. P. de; PEREIRA, J. E. S. Efeito de agentes geleificantes alternativos no meio de cultura no cultivo in vitro de abacaxizeiro e bananeira. Ciência e Agrotecnologia, Lavras, v.31, n.1, p.41-46, 2007.

CUNHA, G.A.P. da; CABRAL, J.R.S.; SOUZA, L.F. da S. (organizadores). $\mathbf{O}$ abacaxizeiro - cultivo, agroindústria e economia. Brasília, DF: Embrapa Comunicação para Transferência de Tecnologia, 1999. 480p.

CUNHA, G.A.P. da; REINHARDT, D.H.R.C. Propagação do abacaxizeiro. Brasília, DF; EMBRAPA/CNPMF, 2004a. 70p. (Coleção Plantar, 11)

CUNHA, G.A.P. da; REINHARDT, D.H.R.C. Manejo de mudas de abacaxi. Cruz das Almas: Embrapa Mandioca e Fruticultura, 2004b. 4p. (Comunicado Técnico, 105)

CUNHA, G.A.P.; REINHARDT, D.H.R.C.; ALMEIDA, O.A.; SOUZA, L.F. da S. Abacaxi. In: MONTEIRO, J.E.B.A. (Org.). Agrometeorologia dos cultivos: o fator meteorológico na produção agrícola. Brasília, DF: INMET, 2009. p.15-32.

EMBRAPA/CNPMF. Relatório Técnico Anual do CNPMF. Cruz das Almas: Centro Nacional de Pesquisa da Mandioca e Fruticultura, 1981. 207 p.
ESCALONA, M.; LORENZO, J. C.; GONZÁLEZ, B.; DAQUINTA, M.; FUNDORA, Z.; BORROTO, C. G.; ESPINOSA, D.; ARIAS, E.; ASPIOLEA, M. E. New system for in-vitro propagation of pineapple (Ananas comosus (L.) Merr.). IICA Tropical Fruits Newsletter, Trinidad, n.29, p.3-5, 1998.

FAO. FAOSTAT. Production. Rome, 2014. Disponível em: $\leq$ http://www.fao.org/faostat/en/\#data/QC $>$. Acesso em: 10 jan. 2017.

FARAHANI, F. Micropropagation and growth of in vitro pineapple (Ananas comosus Merr) in Iran. Plant Archives, Muzaffarnagar, v.14, n.1, p.337-341, 2014.

FEUSER, S.; NODARI, R.O.; GUERRA, M.P. Eficiência comparativa dos sistemas de cultura estacionária e imersão temporária para a micropropagação do abacaxizeiro.

Revista Brasileira de Fruticultura, Jaboticabal, v.23, n.1, p.6-10, 2001.

FOURNIER, P.; BOUFFIN, J.; VANNIERE, H. Cultivation of pineapple 'Queen Victoria' at a very high density in Reunion: Intra-plot variability. In: SYMPOSIUM INTERNATIONAL ANANAS, 2., 1995. Trois-Ilets, Martinique. Abstracts...

FRIEND, D.J.C.; LYDON, J. Effects of daylength on flowering, growth, and CAM (crassulacean acid metabolism) of pineapple (Ananas comosus (L.) Merrill). Botanical Gazette, Chicago, n.140, p.280-283, 1979.

GLENNIE, J.D. Pineapple slip production using the morphactin multiprop applied after flower induction with different chemicals. Australian Journal Experimental Agriculture and Animal Husbandry,Melbourne, n.21, p.121-128, 1981.

GOWING, D.P. Experiments on the photoperiodic response in pineapple. American Journal of Botany, New York, n.48, p.16-21, 1961.

HEENKENDA, H.M.S. Effect of plant size on sucker promotion in 'Mauritius' pineapple by mechanical decapitation. Acta Horticulturae, The Hague, v.334, p.331-336, 1993.

HEENKENDA, H.M.S. Effect of plant density and establishment method on sucker promotion of 'Kew' pineapple by mechanical decapitation. Acta Horticulturae The Hague, v.425, p.321-328, 1995. 
HEPTON, A. Cultural system. In: BARTHOLOMEW, D.P.; PAULL, R.E.; ROHRBACH, K.G. (Ed.). The pineapple: botany, production and uses. New York: Cabi Publishing, 2003. p.109-142.

IBGE. Banco de Dados Agregados. Rio de Janeiro: SIDRA, 2015. Disponível em: $\leq$ http://www2.sidra. ibge.gov.br/bda/tabela/listabl.asp? $\mathrm{c}=1613 \& \mathrm{z}=\mathrm{t} \& \mathrm{o}=11 \mathrm{z}$. Acesso em: 11 nov. 2016.

IRFA - Institut de Recherches sur les Fruits et Agrumes. La culture de l'ananas d'exportation en Cote d'Ivoire: manuel du planteur. Abidjan, 1984. p.65-66.

JUNGHANS, T.G.; JUNGHANS, D.T.; MATOS, E.M.; BATISTA, E.A.; MIELKE, M.S.; LEDO, C.A.S. Seed germination of three pineapple progenies in different temperature regimes. Perspectiva, Erechim, v.39, n.147, p.61-67, 2015.

KEETCH, D.P.; DALLDORF, E.R. Chlorflurenol on smooth cayenne pineapples. Citrus and Subtropical Fruit Research Institute, East London, v.54, p.10-11, 1977. (Information bulletin)

KISS, E.; KISS, J.; GYULAI, G.; HESZKY, L.E. A novel method for rapid micropropagation of pineapple. HortScience, Alexandria, v.30, n.1, p.127-129, 1995.

KRAUSS, B.H. Anatomy of the vegetative organs of the pineapple Ananas comosus (L.) Merr. 1. Introduction, organography, the stem and the lateral branch or axillary buds. Botanical Gazette, Chicago, v.110, p.159-217, 1948.

LIMA, E. da C. A. Propagação clonal in vitro de abacaxizeiros em sistema dupla-fase e conservação de germoplasma sob regime de crescimento mínimo. 2009. 82 f. Tese (Mestrado) - Universidade Federal do Acre, Rio Branco, 2009.

LIMA, V.P. de; REINHARDT, D.H.; COSTA, J.A. Desbaste de mudas tipo filhote do abacaxi cv. Pérola. 1. Produção e qualidade do fruto. Revista Brasileira de Fruticultura, Jaboticabal, v.23, n.3, p.634-638, 2001.

LIMA, V.P. de; REINHARDT, D.H.; COSTA, J.A. Desbaste de mudas tipo filhote do abacaxi cv. Pérola. 2. Análises de crescimento e correlações. Revista Brasileira de Fruticultura, Jaboticabal, v.24, n.1, p. 101-107, 2002.
LUTHER, H.E.; SIEFF, E. An alphabetical list of bromeliad bionomials. $6^{\text {th }}$ ed. Newberg: The Biomeliad Society, 1998. 138 p. Disponível em: <http://selby.org/ wp-content/uploads/Bromeliad_Binomial_List_For_Web. pdf $>$.

MAERERE, A.P. Axillary-bud development as it determines suckering in 'Queen Victoria' and 'Smooth Cayenne' pineapples. Acta Horticulturae, The Hague, v.425, p.309-320, 1995.

MATOS, A.P. de. Doenças e seu controle. In: CUNHA, G.A.P. da; CABRAL, J.R.S.; SOUZA, L.F. da S. O abacaxizeiro - cultivo, agroindústria e economia. Brasília: Embrapa Comunicação para Transferência de Tecnologia, 1999. p. 269-305.

MATOS, A.P. de; REINHARDT, D.H.; SANCHES, N.F.; SOUZA, L.F. da S., TEIXEIRA, F.A.; ELIAS JUNIOR, J.; GOMES, D.C. Produção de mudas sadias de abacaxi. Cruz das Almas: Embrapa Mandioca e Fruticultura, 2009. 11p. (Circular Técnica, 89).

MENDONÇA, V.; MENDONÇA, L.F. de M.; PEREIRA, E.C.; LEITE, G. A.; COSTA, J. M. da; MEDEIROS, F.M.C. de. The growth and nutrition of pineapple (Ananas comosus L.) plantlets under different water retention regimes and manure. African Journal of Agricultural Research, Nairobi, v.12, n.21, p.1852-1860, 2017.

MOREIRA, M.A.; ANJOS SOBRINHO, A.; PASQUAL, M. Indução ao estiolamento in vitro de brotos de abacaxi cv. Pérola. Revista da Universidade de Alfenas, Alfenas, v.5, p.193-197, 1999.

MOREIRA, M.A.; PASQUAL, M.; CARVALHO, J.G. de, FRAGUAS, C.B. Estiolamento na micropropagação do abacaxizeiro cv. Pérola. Ciência e Agrotecnologia, Lavras, v.27, n.5, p.1002-1006, 2003.

MURASHIGE, T.; SKOOG, F. A revised medium for rapid growth and bioassays with tabacoo tissue culture. Physiologia Plantarum, Lund, v.15, p.473-497, 1962.

NASCIMENTO, L.S. do; REINHARDT, D.H. Relatório de estágio. Cruz das Almas: Embrapa Mandioca e Fruticultura, 2005. 11p.

NELSON, B, J.; ASARE, P. A.; ARTHUR JUNIOR, $\mathrm{R}$. In vitro growth and multiplication of pineapple under different duration of sterilization and different concentrations of benzylaminopurine and sucrose. Biotechnology, Faisalãbãd, v.14, n.1, p.35-40, 2015. 
OKIMOTO, M.C. Anatomy and histology of the pineapple inflorescence and fruit. Botanical Gazette, Chicago, v.110, n.2, p.217-231, 1948.

OLIVEIRA-CAUDURO, Y. de; LOPES, V.R.; BONA, C.M. de; ALCANTARA, G.B. de; BIASI, L.A. Micropropagação de abacaxizeiro com enraizamento in vitro e ex vitro. Plant Cell Culture \& Micropropagation, Lavras, v.12, n.2, p.53-60, 2016.

PEREIRA, F. D.; BRAGA, M. F.; SÁ, M. E. L.; ALCINO, O. A. G.; COLENGHI, I. C. Influence of BAP and NAA on multiplication of pineapple cv. Perolera from in vitro etiolated shoots. Bioscience Journal, Uberlândia, v. 17, p. 49-60, 2001.

PINON, A. L'ananas de conserverie et sa culture. Cotê d'Ivoire: Institut de Recherches sur les Fruits et Agrumes, 1978. 82p.

PRAXEDES, S.C.; SILVA JÚNIOR, A.F.; FIGUEIREDO, F.L.B.; FIGUEIREDO, M.L.; CÂMARA, F.A.A.; OLIVEIRA, O.F. Estiolamento in vitro do abacaxizeiro Pérola em presença de ANA e AIA. Caatinga, Mossoró, v.14, n.1/2, p.3-15.2001.

PY, C. La piña tropical. Barcelona: Editorial Blume, 1969. 278p.

PY, C.; LACOEUILHE, J.J.; TEISON, C. L'ananas, sa culture, ses produits. Paris: Editions G.P. Maisonneuve, 1984. 562p.

PY, C.; LACOEUILHE, J.J.; TEISON, C. The pineapple, cultivation and uses. Paris: Editions G.P. Maisonneuve, 1987. 568p.

REBOLLEDO-MARTINEZ|, L., URIZA, D.E., REBOLLEDO-MARTINEZ, A., ZAGADA, G. Suckers production of MD-2 hybrid pineapple by three methods: Gouging, leaf pruning and a growth Regulator. Acta Horticulturae, The Hague, v.666, p.277-285, 2005.

REINHARDT, D.H. A planta e o seu ciclo. In: D.H. Reinhardt, L.F. da S. Souza e J.R.S. Cabral. Abacaxi. Produção: aspectos técnicos. Brasília, DF: Embrapa Comunicação para Transferência de Tecnologia, 2000. p.13-14. (Frutas do Brasil, 7)

REINHARDT, D.H. Clima. In: REINHARDT, D.H.; SOUZA, L.F. DA S.; CABRAL. J.R.S. Abacaxi irrigado em condições semiáridas. Cruz das Almas: Embrapa Mandioca e Fruticultura, 2001. p.11.
REINHARDT. D.H.R.C. Propagação do abacaxizeiro: método usual e por secções de caule. In: SIMPÓSIO BRASILEIRO SOBRE ABACAXICULTURA, 1., 1982, Jaboticabal. Anais... Jaboticabal: FCAV, 1982. p. 14-59.

REINHARDT, D.H.R.C., CUNHA, G.A.P. da. Métodos de produção de mudas de abacaxi livres de fusariose. I. Comportamento de sementeira e viveiro. In: CONGRESSO BRASILEIRO DE FRUTICULTURA, 6., 1982, Recife. Anais... Jaboticabal: Sociedade Brasileira de Fruticultura, 1981. v.1, p.173-92.

REINHARDT, D.H.R.C., CUNHA, G.A.P. da. Métodos de produção de mudas de abacaxi livres de fusariose. 2. Comportamento das plântulas em campo. Cruz das Almas, EMBRAPA/CNPHF, 1982. 14 p. (Boletim de Pesquisa, 1).

REINHARDT, D.H., COSTA, J.T.A., CUNHA, G.A.P. da. Influencia da época de plantio, tamanho da muda e idade da planta para indução floral no abacaxi 'Smooth Cayenne' no Recôncavo Baiano. 1. Crescimento vegetativo, produção de mudas e florescimento natural. Fruits, Paris, v.41, n.1, p.31-41, 1986.

REINHARDT, D.H., COSTA, J.T.A., CUNHA, G.A.P. da. Influencia da época de plantio, tamanho da muda e idade da planta para indução floral no abacaxi 'Smooth Cayenne' no Recôncavo Baiano. 2. Produtividade e características do fruto. Fruits, Paris, v.42, n.1, p.13-23, 1987.

REINHARDT, D.H., CUNHA, G.A.P. da. Método de produção de mudas sadias de abacaxi. 3.ed. Cruz das Almas: EMBRAPA/CNPMF, 1993. 20p. (Circular Técnica, 2).

REINHARDT, D.H.; SOUZA, L.F. da S.; CUNHA, G.A.P. da. Manejo do abacaxi 'Pérola' para produção de rebentões. Revista Brasileira de Fruticultura, Jaboticabal, v.18, n.3, p.319-327, 1996.

REINHARDT, D.H.; CABRAL, J.R.S.; SOUZA, L.F. da S.; SANCHES, N.F.; MATOS, A.P. de. Pérola and Smooth Cayenne pineapple cultivars in the State of Bahia, Brazil: growth, flowering, pests, diseases, yield and fruit quality. Fruits, Paris, v.57, n.1, p.43-53, 2002.

REINHARDT, D. H.; CABRAL, J. R. S.; MATOS,A.P. de; JUNGHANS, D. T. 'BRS Ajubá', a new pineapple cultivar resistant to fusariosis and adapted to subtropical conditions. Acta Horticulturae, The Hague, v. 928, p. 75-79, 2012. 
REINHARDT, D.H.; CUNHA, G.A.P.da; SOUZA, L.F. da S. Clima e solo. In: SANCHES, N.F.; MATOS, A.P. de. (Ed.). Abacaxi: o produtor pergunta, a Embrapa responde. Brasília, DF: Embrapa, 2013. p.15-23.

RITZINGER, R. Recomendação de cultivares de abacaxi para o Acre. Rio Branco: Embrapa-CPAF, 1992.

SANTOS, M. da C.; BARBOZA, S. B. S. C.; LÉDO, A. da S.; VIÉGAS, P. R. A.; COPATI, L. A. Efeito do estiolamento na micropropagação de abacaxi cultivar Imperial. Plant Cell Culture \& Micropropagation, Lavras, v.5, n.2, p.101-110, 2009.

SANTOS, P. C.; FREITAS, S. J.; FREITAS, M. S. M.; SOUSA, L. B.; CARVALHO, A. J. C. Produção de mudas do tipo rebentão, utilizando coroas de três cultivares de abacaxi inoculadas com fungos micorrízicos. Revista Brasileira de Fruticultura, Jaboticabal, v.33, n.3, p.954961, 2011.

SCHERER, R.F.; GARCIA, A.C.; FREITAS, F.H.P., DAL VESCO, L.L., STEINMACHER, D.A.; GUERRA, M.P. Nodule cluster cultures and temporary immersion bioreactors as a high performance micropropagation strategy in pineapple (Ananas comosus var.comosus). Scientia Horticulturae, Leuven, v.151, p.38-45, 2013.

SCHERER, R.F.; HOLDERBAUM, D.F.; GARCIA, A.C.; SILVA, S.A. da; STEINMACHER, D.A.; GUERRA, M.P. Effects of immersion system and gibberellic acid on the growth and acclimatization of micropropagated pineapple. Crop Breeding and Applied Biotechnology, Viçosa, MG, v.15, p.66-71, 2015a.

SCHERER, R.F.; FRAGA, H.P. de F.; KLABUNDE, G.F.; SILVA, D.A. da; GUERRA, M.P. Global DNA methylation levels during the developmentof nodule cluster cultures and assessment of genetic fidelityof in vitro-regenerated pineapple plants (Ananas comosus var.comosus). Journal of Plant Growth Regulator, Dordrecht, v.34, p.677-683, $2015 b$.

SCHERER, R.F.; OLKOSKI, D., SOUZA, F.V.D. Gigante de Tarauacá: a triploid pineapple from Brazilian Amazonia. Scientia Horticulturae, Leuven, v.181, p.13, 2015.

SILVA, A.B.; PASQUAL, M.; TEIXEIRA, J.B.; ARAÚJO, A.G. Métodos de micropropagação de abacaxizeiro. Pesquisa Agropecuária Brasileira, Brasília, DF, v.42, n.9, p.1257-1260, 2007.
SILVA, R.L.; FERREIRA, C.F.; LÊDO, C.A.S.; SOUZA, E.H.; COSTA, M.A.P.C.; SOUZA, F.V.D. Viability and genetic stability of pineapple germplasm after 10 years of in vitro conservation. Plant Cell, Tissue and Organ Culture, Dordrecht, v.127, n.1, p.123-133, 2016.

SOUZA, F.V.D.; SOUZA, A.S.; SANTOS-SEREJO, J.A.; SOUZA, E.H; JUNGHANS, T.G.; SILVA, M.J. Micropropagação do abacaxizeiro e outras bromeliáceas. In: JUNGHANS, T.G.; SOUZA, A.S. (Ed.). Aspectos práticos da micropropagação de plantas. Cruz das Almas: Embrapa Mandioca e Fruticultura Tropical, 2009. p.177-205.

SOUZA, F.V.D.; CANTO, A.M.E.; SOUZA, A. da S.; COSTA, M.A.P. de. Residual effect of growth regulators in etiolation and regeneration of in vitro pineapple plants. Revista Brasileira de Fruticultura, Jaboticabal, v.32, n.2, p.612-617, 2010.

SOUZA, F.V.D.; FERREIRA, F.R.; CABRAL, J.R.S.; SOUZA, E.H. Recursos genéticos do gênero Ananas: passado, presente e futuro. In: SIMPÓSIO DA REDE DE RECURSOS GENÉTICOS VEGETAIS DO NORDESTE, 2., 2015; Fortaleza. Anais... Fortaleza: Embrapa Agroindústria Tropical, 2015. (R 118).

SUWUNNAMEKk, U. Effect of paclobutrazol, thiourea and pendimethalin alone or in combination on the induction of suckering in pineapple. Acta Horticulturae, The Hague, v.334, p.93-99, 1993.

TEIXEIRA, J.B.; CRUZ, A.R.R.; FERREIRA, F.R.; CABRAL, J.R.S. Produção de mudas de abacaxi de alta qualidade através da micropropagação. Brasília, DF: Embrapa Recursos Genéticos e Biotecnologia, 2001a. 26p. (Documentos, 70).

TEIXEIRA, J.B.; CRUZ, A.R.R.; FERREIRA, F.R.; CABRAL, J.R.S. Biotecnologia aplicada à produção de mudas: produção de mudas micropropagadas de abacaxi. Biotecnologia, Ciência e Desenvolvimento, Brasília, DF, v.3, n.19, p.42-47, 2001 b.

TORRES, C.T.; CALDAS, L.S.; BUSO, J.A. Cultura de tecidos e transformação genética de plantas. Brasília, DF: EMBRAPA - SPI/ CNPH, 1999. v.1, 509p.

USMAN, I.S.; ABDULMALIK, M.M.; SANI, AL.A.; MUHAMMAD, A.S. Development of an efficient protocol for micropropagation of pineapple (Ananas comosus L. var. Smooth Cayenne). African Journal of Agricultural Research, Nairobi, v.8, n.18, p.2053-2056, 2013. 
VAN OVERBEECK, J.; CRUZADO, H.J. Note on flower formation in the pineapple induced by low night temperatures. Plant Physiology, Washington, v.23, p.281$285,1948$.

ZHANG, J. Computer simulation of pineapple growth, development, and yield. 1992. Dissertation (PhD) University of Hawaii at Manoa, Honolulu, 1992.
ZURAIDA, A.R.; NURUL SHAHNADZ, A.H.; HARTEENI, A.; ROOWI, S.; CHE RADZIAH, C.M.Z.; SREERAMANAN, S. A novel approach for rapid micropropagation of maspine pineapple (Ananas comosus L.) shoots using liquid shake culture system. African Journal of Biotechnology, Nairobi, v.10, n.19, p.38593866, 2011. 